\title{
1 Biocontrol of Aspergillus niger in 3D-lung cell tissues by oxalotrophic bacteria
}

3 Running title: Bacteria-induced control of Aspergillus

5 Fabio Palmieri ${ }^{1}$, Ilona Palmieri ${ }^{1}$, Nourine Noormamode ${ }^{1}$, Aislinn Estoppey ${ }^{1}$, M. Omar Ishak $^{2}$, 6 Julia M. Kelliher ${ }^{2}$, Armelle Vallat ${ }^{3}$, Rashi Iyer ${ }^{4}$, Saskia Bindschedler ${ }^{1}$, Karen Davenport ${ }^{2}$, Patrick

7 S. G. Chain ${ }^{2}$, Jennifer Foster Harris ${ }^{2}$, Pilar Junier ${ }^{1} *$.

$9{ }^{1}$ Laboratory of Microbiology, Institute of Biology, University of Neuchâtel, Neuchâtel,

10 Switzerland.

$11{ }^{2}$ Bioscience Division, Los Alamos National Laboratory, Los Alamos, NM, USA.

$12{ }^{3}$ Neuchâtel Platform of Analytical Chemistry, University of Neuchâtel, Neuchâtel, Switzerland

$13{ }^{4}$ Analytics, Intelligence and Technology Division, Los Alamos National Laboratory, Los

14 Alamos, NM, USA.

15

$16 *$ Corresponding author

17 E-mail: pilar.junier@unine.ch (PJ) 


\section{Abstract}

Aspergillus fungi are opportunistic pathogens that affect a large number of people worldwide. Many aspects of Aspergillus spp. pathogenesis toward humans are known, but their ability to enhance their infectious potential by manipulating the environmental $\mathrm{pH}$ of its host has not been considered yet. In this study, we tested the hypothesis that by producing oxalic acid, Aspergillus niger can manipulate $\mathrm{pH}$ during lung infection and thus, interfering with this process could limit pathogenicity. To test this hypothesis, we co-cultured A. niger with oxalotrophic bacteria in increasingly complex testing systems (Petri dishes and 3D-cell cultures systems). In in vitro tests, oxalotrophic bacteria limit oxalic acid production and suppressed the $\mathrm{pH}$ shift induced by A. niger. In 3D-cell cultures (Transwells ${ }^{\circledR}$ and Bronchioles-on-a-chip), A. niger also modified $\mathrm{pH}, \mathrm{Ca}^{2+}$ and oxalic acid concentrations. Coinoculation with as little as 10 cells of the oxalatrophic bacterium strongly inhibited the germination and development of A. niger and returned each of the three parameters to the baseline physiological values of uninfected cells. This biocontrol interaction between oxalotrophic bacteria and oxalate-producing A. niger could represent a paradigm shift in the fight against opportunistic fungal pathogens, where the host environment is rendered less permissive to fungal development.

\section{Introduction}

Fungal diseases are estimated to kill more than 1.5 million people every year $(1,2)$. Over the last three decades, the increase in the number of at-risk individuals has correlated with an intensification in the burden of fungal disease on human health (3). As the size of at-risk populations (e.g. immunosuppressed patients) is expected to keep increasing in the future (2), tackling fungal pathogenesis is urgent. However, only a very limited number of antifungal drugs are used nowadays to control fungal pathogens. Because of this restricted chemical arsenal, the same classes of molecules are used in human health, animal husbandry, and agriculture, leading to the rise, and rapid spread, of resistance in fungal pathogens that can affect both plant and animal hosts (4). In spite of this, tackling fungal diseases has been largely neglected up to now (5).

The most prevalent fungal pathogens affecting humans are airborne opportunists such as Aspergillus spp., Cryptococcus spp., Pneumocystis spp., and human-associated commensals 
like Candida albicans $(6,7)$. These fungal species are responsible for approximately $90 \%$ of the deaths due to fungal infection (1). The ecology of all these organisms plays a very significant role in their ability to transition to pathogenic lifestyles. For instance, the remarkable plasticity in the ecology and stress-response of Aspergillus spp. is believed to form the basis of its success as an opportunistic pathogen $(8,9)$.

Although many aspects of the ecology of Aspergillus spp. have been connected to pathogenicity (9), its ability to manipulate $\mathrm{pH}$ via the secretion of low molecular weight organic acids (LMWOA), and in particular, oxalic acid, has been largely ignored in the context of human pathogenesis. Several clinical reports have shown the presence of calcium oxalate $(\mathrm{CaOx})$ crystals in pulmonary aspergillosis in animals and humans (10-15). Oxalic acid and oxalate crystals are thought to directly cause damage to the host tissues (including pulmonary blood vessels), and to generate free radicals which can harm cells indirectly (14). A recent case report of invasive pulmonary aspergillosis in a 69-year old man with lymphoma and pneumonia indicated the presence of $\mathrm{CaOx}$ crystals around blood vessels and within the blood vessel walls. This suggests a potential mechanical role of oxalate crystals in the angioinvasion of Aspergillus (15). However, a link between oxalic acid production and pathogenicity has not yet been made in fungi from this genus or in any other fungal human pathogen. On the contrary, oxalic acid production has been widely acknowledged as a pathogenicity factor in fungal plant pathogens, such as Sclerotinia sclerotiorum and Botrytis cinerea $(16,17)$ where $\mathrm{pH}$ manipulation and calcium chelation plays a direct role in pathogenesis (18-20). Both acidification and cation complexation in the local environment is exploited by plant pathogens to weaken the cell wall structure, facilitate infection, inhibit plant defenses, and induce programmed cell death $(19,21)$.

Oxalic acid is a ubiquitous compound in the environment and is thought to have a central role in fungal metabolism (19). Its production and consumption by microorganisms have been directly associated with $\mathrm{pH}$ regulation in soil (22). In such ecosystems, oxalic acid is often found complexed with divalent cations, especially calcium (23). Despite its chemical stability $\left(\mathrm{K}_{\mathrm{sp}} \mathrm{CaOx}\right.$ monohydrate $\left.=2.32 \times 10^{-9}\right), \mathrm{CaOx}$ rarely accumulates $(24,25)$. This is because oxalate is used by soil oxalotrophic bacteria as carbon and energy sources. The transformation of a strong organic acid into a weaker one (oxalic acid versus carbonic acid; $\mathrm{pK}_{\mathrm{a}}=1.25$ and 4.14 , respectively), leads to a local increase in soil $\mathrm{pH}$. This overall process has been coined out in the oxalate-carbonate pathway (26). Moreover, oxalic acid plays a key role in 
81

82

83

84

85

86

87

88

89

90

91

92

93

94

95

96

bacterial:fungal interactions acting as a signaling cue by bacteria in order to localize fungi and to establish different types of trophic interactions with them (27-29).

In this study we wanted to evaluate whether the metabolic processes associated to oxalic acid during Aspergillus spp. infection could parallel those occurring during its natural cycling in the oxalate-carbonate pathway in soils. Indeed, humans can be seen as a complex ecosystem governed by the same ecological principles affecting any other ecosystem (30). Thus, the ability of oxalotrophic bacteria to degrade oxalic acid produced by Aspergillus spp., and control the subsequent $\mathrm{pH}$ manipulation and calcium chelation, would result in a mechanism to control biologically this opportunistic fungal pathogen (Fig. 1). To test our hypothesis, we selected Aspergillus niger as a model. This organism is regarded as a safe relative of the more infectious Aspergillus fumigatus (31), and has been extensively studied for its ability to produce oxalic acid $(32,33)$. It is also a known agent of aspergillosis in humans, being responsible for $5 \%$ of the cases $(9,34)$. We first confirmed that A. niger secretes oxalic acid and assessed the effect of co-cultivation with oxalotrophic bacteria on $\mathrm{pH}$ and oxalic acid concentration, and on the inhibition of A. niger's growth. This was done in vitro and on human bronchial epithelial cell (HBEC) cultures using two complementary 3D-cell cultures systems (Transwell@ inserts and bronchioles-on-a-chip (BoC)).

\section{Results}

\section{Detection of oxalic acid produced by Aspergillus niger in different culture conditions}

Since the metabolism of fungi can change significantly depending on the nutritional conditions of the growth medium, we first tested whether our fungal strain produced oxalic acid only or a mixture of different organic acids in culture media differing in their trophic conditions. While A. niger is known to produce high amounts of oxalic acid, it is also well known to produce other LMWOA such as citric acid (32, 35-37). An Ultra-High-Performance Liquid Chromatography (UHPLC) analysis revealed that in the conditions we tested, A. niger produced oxalic acid, only (Fig. S1A). The absence of other organic acids is not surprising as the conditions for other LMWOA production are highly specific (e.g. carbon concentration above $50 \mathrm{~g} / \mathrm{L}$ carbon and $\mathrm{pH}<3$; $(38,39)$ and are not provided in the conditions we tested. Acidification and the presence of $\mathrm{CaOx}$ crystals could also be detected in water yeast agar 
111 (WYA) (Fig. S1B). We thus concluded that our A. niger strain consistently produced oxalic

112 acid and acidified the $\mathrm{pH}$ of its medium under laboratory growth conditions.

\section{Confrontation assays between $A$. niger and selected bacterial strains}

115 We assessed how the presence of oxalotrophic bacteria impacted A. niger growth and $\mathrm{pH}$ 116 evolution in different growth media. Two oxalotrophic bacteria (Cupriavidus necator and $C$. 117 oxalaticus) and one non-oxalotrophic bacterium (Pseudomonas putida) were used in 118 confrontation assays. In malt agar diluted 10 times (MA 1/10), A. niger colonized the entire 119 Petri dish, including the area in which the bacterial inocula were applied. All three inoculated 120 bacteria did not survive in the area of interaction with the fungus (Fig. S2A). In Reasoner's 2

121 agar (R2A), A. niger mycelia did not colonize the area beyond the barrier formed by the 122 bacterial inocula, but some hyphae were still able to grow beyond the bacterial inoculation 123 zone and develop into microcolonies in the co-culture with P. putida (Fig. S2B). In WYA, 124 mycelial growth was also restricted to the area delimited by the inocula in the co-culture with 125 the two oxalotrophic bacteria. On the other hand, $P$. putida did not survive the interaction 126 with the fungus, which instead, colonized the entire plate. Moreover, in WYA medium, which 127 contained a pH indicator, the acidification of the medium by the fungus grown alone or in co128 culture with the non-oxalotrophic bacterium was clearly visible. In contrast, in the co-cultures 129 with oxalotrophic bacteria, the $\mathrm{pH}$ of the medium did not change. The control over fungal 130 growth was particularly remarkable in the case of C. oxalaticus (Fig. S2C). Given the impact 131 of the medium on the control of fungal growth, we repeated the confrontation assays in Air132 Liquid Interface (ALI) medium, which is the medium used for differentiation of lung cells 133 (40). The non-oxalotrophic bacterial model ( $P$. putida) acidified the medium when grown 134 alone, while the oxalotrophic bacteria (C. necator and $C$. oxalaticus) did not acidify the 135 medium (Fig S3A). C. oxalaticus was found to not only control mycelial growth but also 136 inhibit conidia germination (Fig. S3B). Moreover, the presence of C. oxalaticus in co-culture 137 with the fungus stabilized the $\mathrm{pH}$ of the culture medium at a neutral $\mathrm{pH}$ (Fig. S3C), consistent 138 with decreased oxalic acid concentration in the medium (Fig. S3D). We therefore conclude 139 that oxalotrophic bacteria have a significant inhibitory effect on A. niger growth in all media 140 tested. 
143 In order to obtain evidence that oxalotrophic bacteria control the growth of $A$. niger in an

144 animal-free lung infection model that is compatible with the $3 \mathrm{R}$ principles of animal

145 experimentation (41), we set up experiments on human bronchial epithelial cell (HBEC)

146 cultures. We established a dose-response curve for increasing conidial and/or bacterial loads

147 on HBECs in submerged cultures, to identify the optimal load to perform experiments in

148 Transwells ${ }^{\circledR}$ and BoC systems. After $24 \mathrm{~h}$, the overall size, shape and integrity of the lung

149 cells changed at an absolute load of 500 conidia and above. The HBECs shrank in size due to

150 actin agglomeration. Moreover, from a conidial load of $>=1000$, fungal growth also had an

151 adverse effect on tissue integrity (Fig. S4). The same experiment was performed with $C$.

152 oxalaticus and P. putida. A strong morphological change was induced by a total load of 500

153 bacterial cells and above for the former (Fig. S5), and as little as 10 cells for the latter (Fig.

154 S6), which was not used further. The HBECs co-cultured with $C$. oxalaticus became rounder,

155 and actin agglomeration increased compared with the cells-only control (Fig. S5).

156 To analyze the effect of co-culturing A. niger with the oxalotrophic bacterium on HBECs

157 integrity, we performed a test with 10 and 500 conidia confronted with 10 bacterial cells.

158 After 72h, A. niger induced morphological changes (size reduction and actin agglomeration),

159 with a stronger effect for 500 conidia, confirming the results obtained at $24 \mathrm{~h}$. With the co-

160 inoculation of as few as 10 C. oxalaticus cells, the morphology of the HBECs was similar to

161 the morphology of HBECs of the bacteria-only control, suggesting the inhibition of fungal

162 development (Fig. S7). We concluded that a conidial and bacterial load of 10 conidia/cells

163 was ideal to monitor the interaction of A. niger and C. oxalaticus in differentiated HBECs in

164 Transwells ${ }^{\circledR}$ and BoC systems.

166 Biocontrol assay of $\boldsymbol{A}$. niger bronchial cells infection by $\boldsymbol{C}$. oxalaticus

167 After establishing a dose-response curve on HBECs in submerged cultures, the effect of 168 inoculation of $10 \mathrm{~A}$. niger conidia alone or in co-culture with $10 \mathrm{C}$. oxalaticus cells was 169 assessed in differentiated bronchial tissue in Transwell@ inserts and BoC systems. In the 170 presence of the fungus alone, changes in three key environmental factors were observed: $\mathrm{pH}$, $171 \mathrm{Ca}^{2+}$ concentration, and concentration of soluble oxalic acid. The $\mathrm{pH}$ dropped significantly 172 from 7.5 down to 4.5 in Transwells ${ }^{\circledR}$ and from 7.3 to 6.8 in $\mathrm{BoC}$ systems (Fig. $3 \mathrm{~A}$ ). $\mathrm{Ca}^{2+}$ 173 concentrations changed from $1 \mathrm{mM}$ to around $0.2 \mathrm{mM}$ in both culture systems (Fig. 3B). The 174 level of soluble oxalic acid produced by A. niger dropped from $500 \mu \mathrm{M}$ (cells alone) to $75 \mu \mathrm{M}$ 
175 (cells inoculated with the fungus) (Fig. 3C). In contrast, $\mathrm{pH}, \mathrm{Ca}^{2+}$ and free oxalic acid levels

176 were statistically indistinguishable when oxalotrophic bacteria were co-cultured with the

177 fungus compared to the controls with lung cells alone or with bacteria. In addition, $\mathrm{CaOx}$

178 crystals were observed in the cultures in which the fungus developed (Fig. 3D), but not when

179 the fungus was co-cultured with oxalotrophic bacteria (Fig. 3E). This suggests that the lower

180 levels of soluble oxalic acid measured in the treatment with the fungus were likely the result

181 of complexation of oxalic acid and $\mathrm{Ca}^{2+}$, and corroborates the $\mathrm{pH}$ and $\mathrm{Ca}^{2+}$ concentration data.

182 Moreover, the absence of $\mathrm{CaOx}$ crystals when the fungus was in co-culture with $C$. oxalaticus

183 agrees with the $\mathrm{pH}, \mathrm{Ca}^{2+}$ concentration and soluble oxalic concentrations measured. These

184 results validated our hypothesis that oxalotrophic bacteria can be used to manipulate the

185 microenvironment created by $A$. niger. In addition to the changes in the environmental

186 parameters measured above, we also observed a cytopathic effect when conidia of A. niger

187 developed into mycelia (Fig. 4A and B). This cytopathic effect resulted in the destruction of

188 the bronchial epithelium. Lactate dehydrogenase (LDH) activity were elevated in response to

189 the presence of the foreign oxalotrophic bacteria (Fig. 4C), something that needs to be

190 addressed for any future therapeutic application.

191

192 Genomic potential for oxalic acid production in other Aspergillus spp.

193 We performed a genomic screening of orthologous genes to the oxaloacetate acetylhydrolase

$194(o a h A)$ and the oxalate/formate antiporter (genes involved in oxalic acid production in $A$.

195 niger) in genomes available in the Aspergillus Genome Database (AspGD). The genomic

196 screening revealed that orthologs of both genes are found in multiple Aspergillus spp. and are

197 highly conserved across diverse species (Fig. 5). In the case of the orthologs to the

198 oxalate/formate antiporter, they were conserved to a lesser extent (Fig. S8). This genomic

199 analysis confirmed that diverse Aspergillus spp. possesses the genes necessary to produce and

200 secrete oxalic acid.

201

202 Discussion

203 Here we present a biological interaction between A. niger and oxalotrophic bacteria that 204 results in the biological control of A. niger, preventing infection in 3D-lung cell tissues 205 (Transwells® and BoC). The direct consequence of acidification through oxalic acid 
206 production by $A$. niger was the decrease in free $\mathrm{Ca}^{2+}$ and subsequent precipitation of $\mathrm{CaOx}$

207 crystals. $\mathrm{CaOx}$ crystals are well known to occur in lung tissues upon infection by A. niger (10,

208 11, 13). Presumably, by consuming the oxalate produced by A. niger, the oxalotrophic

209 bacterial species $C$. oxalaticus blocks the subsequent decrease in $\mathrm{pH}$ and formation of $\mathrm{CaOx}$

210 crystals observed in the absence of the bacterium. To obtain a direct confirmation of the role

211 of oxalic acid in the manipulation of pH during lung infection, the use of a non-oxalate-

212 producer A. niger mutant would be indispensable. Such mutants (oahA gene) are described in

213 the literature and exhibited a decreased acidification of the culture medium and reduced

214 extracellular protease activity $(32,42)$. After multiple failed attempts to obtain the published

215 mutants by addressing the corresponding scientific teams, we attempted to construct a non-

216 oxalate-producer mutant of our A. niger strain using CRISPR-Cas9 gene editing. However,

217 this was unsuccessful due to multiple targets of the sgRNA probes and thus could not be

218 included in this study.

219 Oxalate-degrading bacteria are known inhabitants of the human gut, where they perform the

220 key function of degrading dietary oxalate (43). These species have also been used as

221 probiotics for the treatment of hyperoxaluria (high oxalate in urine) and the management of

222 kidney stones $(43,44)$. While oxalate-degrading bacteria are well characterized in the gut, this

223 is not the case of the lung. Although considered sterile for a long time, the lung is now known

224 to harbor a diverse microbiota $(45,46)$. Oxalate-degrading capabilities have been previously

225 reported in strains of the genera Lactobacillus (47), Streptococcus (48), Prevotella (49, 50)

226 and Veillonella (50), all of which are reported as components of the lung microbiota.

227 However, assessing the oxalotrophic potential of the lung microbiome is something that still

228 need to be accomplished.

229 The genomic analysis of multiple Aspergillus spp. suggests that oxalotrophy could also be 230 relevant to other Aspergillus causing pulmonary aspergillosis (5). The presence of $\mathrm{CaOx}$ 231 crystals during infection by $A$. fumigatus has been reported in the literature $(8,11,14,51)$. 232 Accordingly, we found orthologs of the oxaloacetate acetylhydrolase $(\mathrm{OAH})$ and the 233 oxalate/formate antiporter of $A$. niger in the genomes of two well characterized model $A$. 234 fumigatus strains Af293 and A1163 (52), suggesting the production of oxalic acid by this 235 pathogen and the potential of using oxalotrophic bacteria in fungal species more relevant for 236 human health. To conclude, the results presented here represent a stepping stone towards 237 developing an alternative approach to control the development of oxalate-producing 
238

239

240

241

242

243

244

245

246

247

248

249

250

251

252

253

254

255

256

257

258

259

260

261

262

263

264

265

266

267

268

Aspergillus spp. based on the manipulation of the lung environment using bacterial:fungal interactions.

\section{Materials and Methods}

\section{Bacterial and Fungal cultures}

All bacterial and fungal strains come from the collection of the Laboratory of Microbiology of the University of Neuchâtel (LAMUN; Table 1). P. putida KT2440 was kindly provided by Dr. Arnaud Dechesne (Technical University of Denmark). C. necator JMP289 was kindly provided by Prof. Jan van der Meer (University of Lausanne). C. oxalaticus Ox1 was tagged in-house using insertion with a MiniTn7 system. Table 2 summarizes all the media used. Bacterial strains were routinely cultured on NA medium. Aspergillus niger was routinely cultured on MA medium. PDA was used for A. niger conidia production. BHIA was used to have mycelium-only colony edge without any conidia in order to prevent unwanted conidia dispersal during confrontations with bacteria.

\section{LMWOA detection by UHPLC and by colorimetric pH indicator-based Petri dish assay}

For the UHPLC analysis, $500 \mu \mathrm{l}$ of $30 \mathrm{mM} \mathrm{H}_{2} \mathrm{SO}_{4}$ were added to $1 \mathrm{~mL}$ of a two-week liquid culture in malt 1/10, Reasoner's 2, and ALI liquid media in triplicate, to obtain $20 \mathrm{mM} \mathrm{H}_{2} \mathrm{SO}_{4}$ final concentration in order to obtain a low $\mathrm{pH}$ for the extraction of LMWOAs and to dissolve any precipitated crystals. The samples were incubated at $60^{\circ} \mathrm{C}$ for two hours to dissolve precipitated metal oxalate crystals, and then centrifuged at $3000 \mathrm{~g}$ for $10 \mathrm{~min}$. All the samples were filtered at $0.22 \mu \mathrm{m}(13 \mathrm{~mm}$ syringe filters, PTFE, hydrophilic) and $200 \mu 1$ were added into HPLC vials with $250 \mu \mathrm{l}$ conical inserts. UHPLC (Ultimate 3000 RS-Dionex, Thermo Fisher Scientific, USA) was coupled with DAD detector set at $210 \pm 2 \mathrm{~nm}$. A $5 \mu \mathrm{L}$ of sample was injected onto a Prevail ${ }^{\mathrm{TM}}$ organic acid column $(5 \mu \mathrm{m}$ particle size, $150 \times 4.6 \mathrm{~mm}$, Grace Davison Discovery Sciences, USA) with the temperature kept at $40^{\circ} \mathrm{C}$. The mobile phase consisted of $50 \mathrm{mM}$ phosphate buffer adjusted to $\mathrm{pH} 2.5$ with phosphoric acid with a flow rate of $1 \mathrm{~mL} / \mathrm{min}$. Pure oxalic acid (Merck, Germany) was identified by the retention time and was quantified by an external standard curve, linear regression from five calibration points $(0.2$ to $5 \mathrm{mg} / \mathrm{mL}$ ). For the culture-based assay, WYA supplemented with bromocresol purple (WYA+BP) was used as a $\mathrm{pH}$ indicator-containing medium. After one week of incubation at 
269

270

271

272

273

274

275

276

277

278

279

280

281

282

283

284

285

286

287

288

289

290

291

292

293

294

295

296

297

298

299

room temperature (RT), the presence of typical bi-pyramidal shaped $\mathrm{CaOx}$ crystals was assessed by observing a thin slice of agar medium sampled at the edge of the colony and stained with lactophenol cotton blue under a Leica DM4 B optical microscope connected to a Leica DFC7000 T camera.

\section{Confrontation assays on solid media}

Confrontations assays were performed between A. niger and P. putida, C. necator and C. oxalaticus (Table 1), on three culture media (MA 1/10, R2A and WYA+BP). A plug coming from the apical part of an actively growing A. niger colony was sampled using the wider end of a Pasteur pipette and inoculated in the center of the plates. The bacterial strains were inoculated from fresh plates as opposite lines on either side of the fungal inoculum. Plates were incubated at RT for 20 days, and pictures of the plates at 20 days were taken. Pictures of the bacterial inocula were taken using a Nikon SMZ18 epifluorescence stereoscope, connected to a Nikon DS-Ri2 camera, in order to assess the viability of the bacterial strains thanks to constitutively expressed fluorescent proteins.

\section{Growth tests and confrontation assay in Air-Liquid Interface (ALI) medium}

Bacterial growth in ALI medium was tested for 3 days at RT. To produce conidial suspensions, A. niger was cultured on PDA for 10 days at RT. Conidia were harvested using Dulbecco's Phosphate Buffer Saline (DPBS) supplemented with $0.01 \%$ (v/v) Tween 80. Harvested conidia were washed three times with DPBS following centrifugation at 2000xg for $5 \mathrm{~min}$ at RT. Finally, conidia were resuspended in $2 \mathrm{~mL}$ DPBS and quantified with an Improved Neubauer counting chamber. Two $\mu \mathrm{L}$ of $16^{\prime} 000$ conidia/bacterial cell per $\mu \mathrm{L}$ suspensions were inoculated in $200 \mu \mathrm{L}$ ALI medium. To test mycelial growth in the different media, small agar plugs (approximately $3 \times 3 \mathrm{~mm}$ ) coming from the edge of a colony of $A$. niger on BHIA were used. The 96-well plate was incubated at RT for 7 days and growth was visually assessed.

Confrontation of A. niger with C. oxalaticus was performed in 100-mm Corning® tissue culture plate containing $12 \mathrm{~mL}$ ALI medium to allow the fungus to attach during growth. The fungal inoculum was taken from the apical part of an active colony grown on BHIA by using the wider end of a Pasteur pipette. For the confrontation assay, the fungal inoculum was 
300 placed in the medium after addition and mixing of $100 \mu \mathrm{L}$ inoculum of an overnight culture of

301 C. oxalaticus in ALI medium. A fungus-only plate was used as control. The plates were

302 incubated at RT for 7 days. Oxalic acid concentration was quantified by using the Oxalic Acid

303 Colorimetric Assay Kit (Sigma-Aldrich, Germany), following the manufacturer instructions.

304

305 Preparation and sterilization of the bronchiole-on-a-chip (BoC)

306 The chip was assembled as described in Hsieh et al. (53). Each unit of the culture platform 307 was fabricated by using a layer-by-layer stacking technique (54). The devices were designed 308 using Solid Edge 2D software (ST9, Siemens PLM Software), and each layer of the 309 prelaminated polymeric sheet was obtained using a $\mathrm{CO}_{2}$ laser cutter (Universal Laser 310 System). The prelaminated polymeric sheets were combined with biocompatible adhesive 311 tapes (9122, 3M Company) with PMMA (1.5 and $3 \mathrm{~mm}$ thick) or PET (0.1 and 0.25mm 312 thick). After cutting, each layer was aligned and assembled using a seam roller to complete 313 the devices. The culture chip includes a Y-shaped apical and a basal part separated by a 314 porous PET membrane (pore size $=0.4 \mu \mathrm{m}$ ) prepared as described in Arefin et al. (55). The 315 PET membrane was sandwiched between two PET sheets using adhesive transfer tape to 316 create the cell culture surface. This allows nutrients to pass from the media to the cells 317 through the porous membrane. The open design of the tissue chip makes cell seeding 318 procedure easy and accessible.

319 For sterilization, each chip was placed in a $100 \mathrm{~mm}$ Petri dish and sterilized with $5 \% \mathrm{H}_{2} \mathrm{O}_{2}$ 320 solution for $1 \mathrm{~h}$. The chips were then rinsed 2-3 times with sterile deionized water for $15 \mathrm{~min}$ 321 between each rinse. Once all liquid was removed, the chips were let dry overnight under a laminar flow hood. The next day, the inlet and outlet of the chip were connected with a sterile tubing and rinsed 3 more times with sterile deionized water as explained before. After the last rinse, $200 \mu \mathrm{l}$ sterile DPBS was added in the channel (apical part) and $5 \mathrm{~mL}$ in the basolateral part (bottom part) of the chip, and the chip was placed in a humidified incubator at $37^{\circ} \mathrm{C}$ with $5 \% \mathrm{CO}_{2}$ overnight. The next morning, peroxide contamination was checked in each chip using a CG8+ i-STAT cartridge (Abbott, USA). Rinses with sterile deionized water and overnight incubation with sterile DPBS were repeated until peroxide was no longer detected.

329 
331 Primary normal human bronchial epithelial cells (Lifeline Cell Technology, USA) were 332 expanded in a T-75 cell culture flask with vent cap (Corning, USA) in BronchiaLife ${ }^{\mathrm{TM}} \mathrm{B} / \mathrm{T}$

333

334

335

336

337

338

339

341

342

343

344

345

346

347

348

349

350

351

352

353

354

355

356

357

358

359

360

361

362 complete medium (Lifeline Cell Technology, USA) supplemented with 0.5\% Phenol Red solution (Sigma-Aldrich, USA, $15 \mathrm{mg} / \mathrm{L}$ final concentration) to $70-80 \%$ confluence in a humidified incubator at $37^{\circ} \mathrm{C}$ with $5 \% \mathrm{CO}_{2}$. Culture medium was changed every other day. Cells were used until passage 2 for all experiments. Cells were harvested by trypsinization with $0.05 \%$ Trypsin / $0.02 \%$ EDTA (Lifeline Cell Technology, USA), followed by the addition of Trypsin Neutralizing buffer (Lifeline Cell Technology, USA), and counted using a hemocytometer after centrifugation at $100 \mathrm{xg}$ for $5 \mathrm{~min}$ and resuspension of the cell pellet in BronchiaLife ${ }^{\mathrm{TM}}$ medium.

Cells were seeded at a density of $3 \times 10^{4}$ cells/well in $200 \mu$ BronchiaLife ${ }^{\mathrm{TM}}$ medium for submerged undifferentiated tissue culture in 96-well plates, and $5 \times 10^{4}$ cells and $8.6 \times 10^{4}$ cells in $200 \mu \mathrm{L}$ BronchiaLife ${ }^{\mathrm{TM}}$ medium for air-lifted differentiated tissue culture in the apical side of Transwell@ inserts in 24-well plates (Corning, USA) and $\mathrm{BoC}$ devices, respectively. Transwell@ inserts and $\mathrm{BoC}$ were first coated with collagen $(30 \mu \mathrm{g} / \mathrm{mL})$ prior seeding of the cells in order to allow proper cell attachment onto the porous membrane, as described in Arefin et al. (55). $600 \mu \mathrm{L}$ of BronchiaLife ${ }^{\mathrm{TM}}$ medium was added to the basolateral side of Transwell@ inserts in the 24 -well plates and $3 \mathrm{~mL}$ in the basolateral side of the $\mathrm{BoC}$ device. 96-well plates, Transwell® inserts, and BoC devices were placed in a humidified incubator at $37^{\circ} \mathrm{C}$ with $5 \% \mathrm{CO}_{2}$ for 2-3 days until confluence and formation of a monolayer of bronchial cells. For differentiated bronchial cell tissues (Transwells ${ }^{\circledR}$ and BoCs), cells were shifted to air-liquid interface by removing carefully the BronchiaLife ${ }^{\mathrm{TM}}$ medium from the apical side and replacing it by Air-Liquid Interface (ALI) Epithelial Differentiation Medium (Lifeline Cell Technology, USA) supplemented with $0.5 \%$ Phenol Red solution (Sigma-Aldrich, USA, $15 \mathrm{mg} / \mathrm{L}$ final concentration). The same was done for the medium on the basolateral side. Finally, the medium on the apical side was removed and the inserts and devices were placed in a humidified incubator at $37^{\circ} \mathrm{C}$ with $5 \% \mathrm{CO}_{2}$ for 21 days. Medium was changed every other day as described previously. The cultures were observed daily using an EVOS ${ }^{\mathrm{TM}}$ XL Core bright field inverted microscope (Thermo Fisher Scientific, USA).

Determination of conidial and bacterial load and confrontation assay on submerged undifferentiated bronchial epithelial cell cultures 
363 In order to determine the optimal conidial and bacterial load to be used for confrontation on

364 bronchial tissue cultures, increasing conidial and bacterial loads were tested to assess their

365 effect on the morphology of bronchial epithelial cells in submerged cultures. A. niger was

366 cultured on PDA for 7 days at $37^{\circ} \mathrm{C}$ in order to produce conidia. A. niger conidia were then

367 harvested as already described. Finally, conidia were resuspended in $2 \mathrm{~mL}$ DPBS and

368 quantified with an Improved Neubauer counting chamber. Bacteria were cultured in

369 BronchiaLife ${ }^{\mathrm{TM}}$ medium at $37^{\circ} \mathrm{C}$ overnight and quantified with an Improved Neubauer

370 counting chamber. A stock suspension of $A$. niger conidia was made at $10^{6}$ conidia/mL that

371 was diluted further to obtain suspensions at $5 \times 10^{5}$ to $5 \times 10^{3}$ and $10^{3}$ conidia/mL. The same

372 was done for $C$. oxalaticus from a stock suspension at $10^{5}$ bacterial cells $/ \mathrm{mL}$ diluted until $10^{3}$

373 bacterial cells $/ \mathrm{mL}$. $10 \mu \mathrm{L}$ of each suspension was added to submerged undifferentiated

374 bronchial tissue in a 96-well plate in order to have $10^{4}$ to 10 conidia/well $(200 \mu \mathrm{L})$ for $A$.

375 niger, and $10^{3}$ to 10 bacterial cells/well $(200 \mu \mathrm{L})$ for $C$. oxalaticus. The plates were placed in

376 a humidified incubator at $37^{\circ} \mathrm{C}$ with $5 \% \mathrm{CO}_{2}$ for $24 \mathrm{~h}$. For the confrontations assay, cells were

377 infected with 10 or 500 A. niger conidia and were put in confrontation with 10 bacterial cells.

378 The plate was placed in a humidified incubator at $37^{\circ} \mathrm{C}$ with $5 \% \mathrm{CO}_{2}$ for $72 \mathrm{~h}$. After

379 incubation, cells were fixed, stained (actin and nucleus), and imaged as described below

380 (Immunofluorescence staining).

381

382 Confrontations on differentiated bronchial tissues in Transwell@ inserts and BoC 383 devices

384 Differentiated bronchial tissues in Transwell® inserts and in BoC devices were infected with $38510 \mu \mathrm{L}$ of $10^{3}$ conidia or bacterial cell to get 10 conidia or bacterial cells. Fungus and bacteria 386 were co-inoculated for the confrontation and controls with only medium, cells, fungus or 387 bacteria were included. Each condition was done in triplicate for the Transwell@ inserts and 388 one unique replicate for each condition was done for the BoC devices. All Transwell@ inserts 389 and $\mathrm{BoC}$ devices were incubated in a humidified incubator at $37^{\circ} \mathrm{C}$ with $5 \% \mathrm{CO}_{2}$ for $72 \mathrm{~h}$.

\section{Immunofluorescence staining}

392 Undifferentiated and differentiated bronchial tissues (Transwell® and BoCs) were fixed with $393100 \mu \mathrm{L} \mathrm{4 \%}$ paraformaldehyde in DPBS for $15 \mathrm{~min}$ at RT. Cells were then rinsed 3 times with 
394

395

396

397

398

399

400

401

402

403

404

405

406

407

408

409

410

411

412

413

414

415

416

417

418

419

420

421

422

423

424

425

$200 \mu \mathrm{L}$ DPBS, with 2 min waiting time between each rinse. Cells were permeabilized with $100 \mu \mathrm{L} 0.5 \%$ Triton X-100 in DPBS for 15 min at RT and rinsed 3 times with $200 \mu \mathrm{L}$ DPBS, with 2 min waiting time between each rinse. After that, cells were blocked with $100 \mu \mathrm{L} 3 \%$ BSA in DPBS for $1 \mathrm{~h}$ at RT. Anti-Mucin 5AC mouse monoclonal antibody (Abcam, USA, Cat.\# ab218466) was prepared in DPBS (1/100). The actin stain (ActinGreen ${ }^{\mathrm{TM}} 488$ ReadyProbes $^{\mathrm{TM}}$ Reagent) and the nuclei counterstain (NucBlue $^{\mathrm{TM}}$ Live ReadyProbes ${ }^{\mathrm{TM}}$ Reagent) were added to the same buffer ( 2 drops $/ \mathrm{mL}$ and 1 drop/mL, respectively). AntiAspergillus rabbit polyclonal antibody (Abcam, Cat.\# ab20419) was also added (1/200) in the staining buffer for the conditions where A. niger conidia were inoculated. Fixed cells were incubated with $100 \mu \mathrm{L}$ buffer containing the stains and Anti-Mucin 5AC and Anti-Aspergillus antibodies overnight at $4^{\circ} \mathrm{C}$. The next day, fixed cells were washed 3 times with DPBS and secondary antibodies were applied. Goat anti-Mouse IgG antibody (1/250) conjugated with Alexa Fluor 546 (Thermo Fisher Scientific, USA, Cat.\# A-11003,) directed against AntiMucin 5AC antibody and Goat anti-Rabbit IgG antibody (1/500) conjugated with Alexa Fluor 594 (Thermo Fisher Scientific, USA, Cat.\# A-11012) directed against Anti-Aspergillus antibody were prepared in DPBS. Fixed cells were incubated with $100 \mu \mathrm{L}$ buffer containing the secondary antibodies overnight at $4^{\circ} \mathrm{C}$. The following day, fixed cells were once again washed 3 times with DPBS and the membranes from the inserts were carefully cut out with a sharp knife. The membranes were mounted on a glass slide using Fluoromount-G ${ }^{\mathrm{TM}}$ Mounting Medium (Thermo Fisher Scientific, USA) and imaged with a Zeiss Axio Observer Z1 fluorescence inverted microscope (Carl Zeiss AG, Germany).

\section{pH measurements and quantification of calcium, oxalic acid and lactate dehydrogenase} (LDH)

$\mathrm{pH}$ measurements of the culture medium after $72 \mathrm{~h}$ incubation were done directly after taking the samples out of the incubator using pH-indicator strips (Merck, Germany) for the Transwell@ inserts samples, and CG8+ i-STAT cartridges for the BoC devices, as the $\mathrm{pH}$ change of the culture medium indicator was less visible. Free calcium (Calcium Colorimetric Assay, Sigma-Aldrich, Germany), free oxalic acid (Oxalic Acid Colorimetric Assay Kit), and LDH (ScienCell Research Laboratories, USA) were quantified in the culture medium using colorimetric assay kits following the manufacturer instructions. 
bioRxiv preprint doi: https://doi.org/10.1101/2020.08.20.259929; this version posted December 20, 2020. The copyright holder for this preprint

(which was not certified by peer review) is the author/funder, who has granted bioRxiv a license to display the preprint in perpetuity. It is made available under aCC-BY-NC-ND 4.0 International license.

\section{Statistical analyses}

427 Statistical significance of the data from the confrontations on differentiated bronchial tissues

428 in Transwell ${ }^{\circledR}$ inserts ( 3 replicates, $\mathrm{n}=3$ ) was tested with unpaired two-tailed Student t-tests 429 in Microsoft ${ }^{\circledR}$ Excel (Version 16.37). The statistical significance threshold was set to 5\%. 


\section{Acknowledgments}

431 We would like to thank Diego Gonzales and Ted Turlings for critical review of the paper, and

432 Pulak Nath from the Materials Physics and Applications Division of the Los Alamos National

433 Laboratory for providing the equipment and laboratory infrastructure for the BoC devices

434 fabrication. BoC devices were developed under Defense Threat Reduction Agency (DTRA)

435 interagency agreement CBMXCEL-XL1-2-0001. Funding: This work was supported by the

436 Novartis Foundation (FreeNovation program), the Gebert Rüf Stiftung (Grant agreement

437 GRS-064/18) and the U.S. Department of Energy, Office of Science, Biological and 438 Environmental Research Division, under award number LANLF59T. Data and materials 439 availability: All data is available in the main text or the supplementary materials.

440

441 Conflict of interests

442 Authors declare no conflict of interests.

443 


\section{$444 \quad$ References}

445 1. Fisher MC, Gurr SJ, Cuomo CA, Blehert DS, Jin H, Stukenbrock EH, et al. Threats 446 posed by the fungal kingdom to humans, wildlife, and agriculture. mBio. 2020;11(3).

447 2. Bongomin F, Gago S, Oladele RO, Denning DW. Global and multi-national 448 prevalence of fungal diseases-estimate precision. 2017.

449 3. Ramirez-Ortiz ZG, Means TK. The role of dendritic cells in the innate recognition of 450 pathogenic fungi (A. fumigatus, C. neoformans and C. albicans). 2012. p. 635-46.

451 4. Fisher MC, Hawkins NJ, Sanglard D, Gurr SJ. Worldwide emergence of resistance to 452 antifungal drugs challenges human health and food security. 2018. p. 739-42.

453 5. Brown GD, Denning DW, Gow NAR, Levitz SM, Netea MG, White TC. Hidden 454 killers: Human fungal infections. 2012. p. 165rv13-rv13.

455 6. Brunke S, Mogavero S, Kasper L, Hube B. Virulence factors in fungal pathogens of 456 man. 2016. p. 89-95.

457 7. Pfaller MA, Diekema DJ. Rare and emerging opportunistic fungal pathogens: Concern 458 for resistance beyond Candida albicans and Aspergillus fumigatus. 2004. p. 4419-31.

459 8. Kousha M, Tadi R, Soubani AO. Pulmonary aspergillosis: A clinical review. 2011. p. $460 \quad 156-74$.

461 9. Paulussen C, Hallsworth JE, Álvarez-Pérez S, Nierman WC, Hamill PG, Blain D, et

462 al. Ecology of aspergillosis: insights into the pathogenic potency of Aspergillus fumigatus and 463 some other Aspergillus species. Microbial Biotechnology. 2017;10(2):296-322.

464 10. Kurrein F, Path FRC, Green GH, Rowles SL. Localized deposition of calcium oxalate 465 around a pulmonary Aspergillus niger fungus ball. American Journal of Clinical Pathology. 466 1975;64(4):556-63.

467 11. Maeno T, Sasaki M, Shibue Y, Mimura K, Oka H. Calcium oxalate in the sputum may 468 aid in the diagnosis of pulmonary aspergillosis: A report of two cases. Medical Mycology 469 Case Reports. 2015;8:32-6.

470 12. Muntz FHA. Oxalate-producing pulmonary aspergillosis in an alpaca. Veterinary 471 Pathology. 1999;36(6):631-2.

472 13. Oda M, Saraya T, Wakayama M, Shibuya K, Ogawa Y, Inui T, et al. Calcium oxalate 473 crystal deposition in a patient with Aspergilloma due to Aspergillus niger. Journal of thoracic 474 disease. 2013;5(4):E174-8.

475 14. Payne CL, Dark MJ, Conway JA, Farina LL. A retrospective study of the prevalence 476 of calcium oxalate crystals in veterinary Aspergillus cases. Journal of Veterinary Diagnostic 477 Investigation. 2017;29(1):51-8.

478 15. Yi Y, Cho SY, Lee DG, Jung JI, Park YJ, Lee KY. Invasive Pulmonary Aspergillosis 479 Due to Aspergillus awamori: Role of Calcium Oxalate Crystal Precipitation Mimicking 480 Mucormycosis. 2020. p. 409-11. 
481 16. Cessna SG, Sears VE, Dickman MB, Low PS. Oxalic acid, a pathogenicity factor for 482 Sclerotinia sclerotiorum, suppresses the oxidative burst of the host plant. Plant Cell. 483 2000;12(11):2191-9.

484 17. Schoonbeek H-j, Jacquat-Bovet A-C, Mascher F, Métraux J-P. Oxalate-degrading 485 bacteria can protect Arabidopsis thaliana and crop plants against Botrytis cinerea. Molecular 486 plant-microbe interactions. 2007;20(12):1535-44.

487 18. Lehner A, Meimoun P, Errakhi R, Madiona K, Barakate M, Bouteau F. Toxic and 488 signalling effects of oxalic acid. Canadian Journal of Microbiology. 2008;3(September):7464898.

490 19. Dutton MV, Evans CS. Oxalate production by fungi: its role in pathogenicity and 491 ecology in the soil environment. Canadian Journal of Microbiology. 1996;42(9):881-95.

492 20. Palmieri F, Estoppey A, House GL, Lohberger A, Bindschedler S, Chain PSG, et al. 493 Oxalic acid, a molecule at the crossroads of bacterial-fungal interactions. In: Gadd GM, 494 Sariaslani S, editors. 106: Academic Press; 2019. p. 49-77.

495 21. de Oliveira Ceita G, Macêdo JNA, Santos TB, Alemanno L, da Silva Gesteira A, 496 Micheli F, et al. Involvement of calcium oxalate degradation during programmed cell death in 497 Theobroma cacao tissues triggered by the hemibiotrophic fungus Moniliophthora perniciosa. 498 Plant Science. 2007;173(2):106-17.

499 22. Graustein WC, Cromack K, Sollins P. Calcium oxalate: Occurrence in soils and effect 500 on nutrient and geochemical cycles. Science. 1977;198(4323):1252-4.

501 23. Martin G, Guggiari M, Bravo D, Zopfi J, Cailleau G, Aragno M, et al. Fungi, bacteria 502 and soil pH: The oxalate-carbonate pathway as a model for metabolic interaction. 503 Environmental Microbiology. 2012;14(11):2960-70.

504 24. Hofmann BA, Bernasconi SM. Review of occurrences and carbon isotope 505 geochemistry of oxalate minerals: implications for the origin and fate of oxalate in diagenetic 506 and hydrothermal fluids. Chemical Geology. 1998;149(1-2):127-46.

507 25. Certini G, Corti G, Ugolini FC. Vertical trends of oxalate concentration in two soils 508 under Abies alba from Tuscany (Italy). Journal of Plant Nutrition and Soil Science. 509 2000;163(2):173-7.

510 26. Braissant O, Cailleau G, Aragno M, Verrecchia EP. Biologically induced 511 mineralization in the tree Milicia excelsa (Moraceae): its causes and consequences to the 512 environment. Geobiology. 2004;2(1):59-66.

513 27. Rudnick MB, van Veen JA, de Boer W. Oxalic acid: A signal molecule for fungus-

514 feeding bacteria of the genus Collimonas? Environmental Microbiology Reports. 515 2015;7(5):709-14.

516 28. Mela F, Fritsche K, De Boer W, Van Veen JA, De Graaff LH, Van Den Berg M, et al. 517 Dual transcriptional profiling of a bacterial/fungal confrontation: Collimonas fungivorans 518 versus Aspergillus niger. ISME Journal. 2011;5(9):1494-504. 
519 29. Haq IU, Zwahlen RD, Yang P, van Elsas JD. The Response of Paraburkholderia terrae

520 Strains to Two Soil Fungi and the Potential Role of Oxalate. Frontiers in Microbiology.

$5212018 ; 9(989)$.

522 30. Dethlefsen L, McFall-Ngai M, Relman DA. An ecological and evolutionary

523 perspective on human-microbe mutualism and disease. Nature. 2007;449(7164):811-8.

524 31. Schuster E, Dunn-Coleman N, Frisvad J, Van Dijck P. On the safety of Aspergillus 525 niger - A review. 2002. p. 426-35.

526 32. Ruijter GJG, van de Vondervoort PJI, Visser J. Oxalic acid production by Aspergillus

527 niger: an oxalate-non-producing mutant produces citric acid at $\mathrm{pH} 5$ and in the presence of 528 manganese. Microbiology. 1999;145(9):2569-76.

529 33. Cameselle C, Bohlmann JT, Núñez MJ, Lema JM. Oxalic acid production by 530 Aspergillus niger. Bioprocess Engineering. 1998;19(4):247-52.

531 34. Person AK, Chudgar SM, Norton BL, Tong BC, Stout JE. Aspergillus niger: An 532 unusual cause of invasive pulmonary aspergillosis. Journal of Medical Microbiology. 533 2010;59(7):834-8.

534 35. Plassard C, Fransson P. Regulation of low-molecular weight organic acid production 535 in fungi. 2009. p. 30-9.

536 36. Show PL, Oladele KO, Siew QY, Aziz Zakry FA, Lan JCW, Ling TC. Overview of 537 citric acid production from Aspergillus niger. 2015. p. 271-83.

538 37. Sturm EV, Frank-Kamenetskaya O, Vlasov D, Zelenskaya M, Sazanova K, Rusakov 539 A, et al. Crystallization of calcium oxalate hydrates by interaction of calcite marble with 540 fungus Aspergillus Niger. American Mineralogist. 2015;100(11-12):2559-65.

541 38. Karaffa L, Kubicek CP. Aspergillus niger citric acid accumulation: do we understand 542 this well working black box? Appl Microbiol Biotechnol. 2003;61(3):189-96.

543 39. Kobayashi K, Hattori T, Honda Y, Kirimura K. Oxalic acid production by citric acid544 producing Aspergillus niger overexpressing the oxaloacetate hydrolase gene oahA. J Ind 545 Microbiol Biotechnol. 2014;41(5):749-56.

546 40. Fulcher ML, Gabriel S, Burns KA, Yankaskas JR, Randell SH. Well-differentiated 547 human airway epithelial cell cultures. Methods in molecular medicine. 2005;107:183-206.

548 41. Kendall LV, Owiny JR, Dohm ED, Knapek KJ, Lee ES, Kopanke JH, et al. 549 Replacement, Refinement, and Reduction in Animal Studies With Biohazardous Agents. 550 ILAR journal. 2018;59(2):177-94.

551 42. Han Y, Joosten HJ, Niu W, Zhao Z, Mariano PS, McCalman M, et al. Oxaloacetate 552 hydrolase, the C-C bond lyase of oxalate secreting fungi. Journal of Biological Chemistry. 553 2007;282(13):9581-90.

554 43. Abratt VR, Reid SJ. Oxalate-degrading bacteria of the human gut as probiotics in the 555 management of kidney stone disease. 72: Academic Press; 2010. p. 63-87. 
556 44. Hoppe B, Von Unruh G, Laube N, Hesse A, Sidhu H, editors. Oxalate degrading

557 bacteria: New treatment option for patients with primary and secondary

558 hyperoxaluria?2005/11//.

559 45. Enaud R, Prevel R, Ciarlo E, Beaufils F, Wieërs G, Guery B, et al. The Gut-Lung Axis

560 in Health and Respiratory Diseases: A Place for Inter-Organ and Inter-Kingdom Crosstalks.

5612020.

562 46. Mitchell AB, Oliver BGG, Glanville AR. Translational aspects of the human 563 respiratory virome. 2016. p. 1458-64.

564 47. Turroni S, Vitali B, Bendazzoli C, Candela M, Gotti R, Federici F, et al. Oxalate 565 consumption by lactobacilli: Evaluation of oxalyl-CoA decarboxylase and formyl-CoA 566 transferase activity in Lactobacillus acidophilus. Journal of Applied Microbiology. 567 2007;103(5):1600-9.

568 48. Miller AW, Dearing D. The metabolic and ecological interactions of oxalate569 degrading bacteria in the mammalian gut. 2013. p. 636-52.

570 49. Ticinesi A, Nouvenne A, Chiussi G, Castaldo G, Guerra A, Meschi T. Calcium 571 oxalate nephrolithiasis and gut microbiota: Not just a gut-kidney axis. a nutritional 572 perspective. 2020.

573 50. Suryavanshi MV, Bhute SS, Jadhav SD, Bhatia MS, Gune RP, Shouche YS. 574 Hyperoxaluria leads to dysbiosis and drives selective enrichment of oxalate metabolizing 575 bacterial species in recurrent kidney stone endures. Scientific Reports. 2016;6(1).

576 51. Pabuççuo $\square$ lu U. Aspects of oxalosis associated with aspergillosis in pathology 577 specimens. Pathology Research and Practice. 2005;201(5):363-8.

578 52. Bertuzzi M, van Rhijn N, Krappmann S, Bowyer P, Bromley MJ, Bignell EM. On the 579 lineage of Aspergillus fumigatus isolates in common laboratory use. Medical Mycology. 580 2020:myaa075-myaa.

581 53. Hsieh HL, Nath P, Huang JH. Multistep Fluidic Control Network toward the 582 Automated Generation of Organ-on-a-Chip. ACS Biomaterials Science and Engineering. 583 2019;5(9):4852-60.

58454 Lin CK, Hsiao YY, Nath P, Huang JH. Aerosol delivery into small anatomical airway 585 model through spontaneous engineered breathing. Biomicrofluidics. 2019;13(4):044109-.

586 55. Arefin A, McCulloch Q, Martinez R, Martin SA, Singh R, Ishak OM, et al. 587 Micromachining of Polyurethane Membranes for Tissue Engineering Applications. ACS 588 Biomaterials Science and Engineering. 2018;4(10):3522-33.

589 56. Nelson KE, Weinel C, Paulsen IT, Dodson RJ, Hilbert H, Martins dos Santos VAP, et 590 al. Complete genome sequence and comparative analysis of the metabolically versatile 591 Pseudomonas putida KT2440. Environmental Microbiology. 2002;4(12):799-808.

592 57. Sentchilo V, Czechowska K, Pradervand N, Minoia M, Miyazaki R, Van Der Meer 593 JR. Intracellular excision and reintegration dynamics of the ICEclc genomic island of 594 Pseudomonas knackmussii sp. strain B13. Molecular Microbiology. 2009;72(5):1293-306. 
595 58. Şahin N, Işik K, Tamer AÜ, Goodfellow M. Taxonomic position of 'Pseudomonas 596 oxalaticus' strain Ox1(T) (DSM 110(T)) (Khambata and Bhat, 1953) and its description in the 597 genus Ralstonia as Ralstonia oxalatica comb, nov. Systematic and Applied Microbiology. 598 2000;23(2):206-9.

599 59. Imeria Ferro K. The impact of oxalogenic plants on soil carbon dynamics - formation 600 of a millennium carbon storage as calcium carbonate. Neuchâtel: University of Neuchâtel; 6012012.

602 60. Reasoner DJ, Geldreich EE. A new medium for the enumeration and subculture of 603 bacteria from potable water. Applied and Environmental Microbiology. 1985;49(1):1-7.

604 


\section{Figure legends}

606 Fig. 1. Schematic summary of the proposed strategy to control Aspergillus niger 607 infection by introducing oxalotrophic bacteria to modify the $A$. niger environmental 608 niche. (A) A. niger conidia (depicted in dark grey) arrive in the respiratory system through 609 breathing. (B) During a normal infection process in a susceptible host, A. niger modifies the 610 environment by secreting oxalic acid (or oxalate $\mathrm{Ox}^{2-}$ ) which decreases $\mathrm{pH}$ and chelates free 611 calcium in the form of $\mathrm{CaOx}$ (depicted in light grey) crystals. This results in the infection of 612 the host's tissue. (C) The biocontrol strategy proposed here takes advantage of the ability of 613 oxalotrophic bacteria (cells depicted in red) to consume $\mathrm{CaOx}$ and thus reestablish 614 physiological $\mathrm{pH}$ and free calcium concentrations.

616 Fig. 2. Comparison of the growth of Aspergillus niger (An) alone and in confrontation 617 with Cupriavidus oxalaticus (Co) in different culture media. The red line next to each 618 picture represents the extent of $A$. niger growth. On MA 1/10 (A), there is no significant 619 growth inhibition of A. niger, as it kills C. oxalaticus. A. niger growth is highly restricted to 620 the center of the plate when co-cultured with C. oxalaticus on R2A (B). The growth inhibition 621 of A. niger when co-cultured with C. oxalaticus is less pronounced on WYA + BP. Moreover, 622 the presence of $\mathrm{C}$. oxalaticus revert the $\mathrm{pH}$ of the medium to a neutral value (C). A yellow 623 color indicates an acidic $\mathrm{pH}<6$.

625 Fig. 3. Influence of the interaction between Aspergillus niger and the oxalotrophic 626 bacterium Cupriavidus oxalaticus on environmental parameters of differentiated 627 bronchial tissue in Transwell ${ }^{\circledR}$ inserts and bronchiole-on-a-chip (BoC) devices. In the 628 presence of the fungus, the $\mathrm{pH}(\mathrm{A})$ decreases, as compared to all other treatments. This $\mathrm{pH}$ 629 decrease is correlated with a drastic decrease in the concentration of free $\mathrm{Ca}^{2+}(\mathrm{B})$ ( $p$-value 630 between $\mathrm{C}$ and $\mathrm{C}+\mathrm{F}=8,951 \times 10^{-7}$ ). Free oxalic acid concentrations were lower in the 631 presence of the fungus, compared with the basal level secreted by the bronchial cells (C) ( $p$ 632 value between $\mathrm{C}$ and $\mathrm{C}+\mathrm{F}=4,587 \times 10^{-8}$ ). These results are supported by the detection of $633 \mathrm{CaOx}$ crystals in the presence of the fungus (D). In the co-culture with the oxalotrophic 634 bacterium, $\mathrm{pH}$, free $\mathrm{Ca}^{2+}$ and free oxalic acid concentrations return to physiological levels, 635 and this was concomitant with the absence of crystals $(\mathrm{E})(p$-values between $\mathrm{C}+\mathrm{F}$ and $\mathrm{C}+\mathrm{F}+\mathrm{B}$ 
636 for free $\mathrm{Ca}^{2+}$ and free oxalic acid $=0,002$ and $1,415 \times 10^{-7}$, respectively). C: lung cells; $\mathrm{C}+\mathrm{F}$ :

637 lung cells + fungus; $\mathrm{C}+\mathrm{B}$ : lung cells + bacteria; $\mathrm{C}+\mathrm{F}+\mathrm{B}$ : lung cells + fungus + bacteria. For $\mathrm{A}$,

$638 \mathrm{~B}, \mathrm{C}$, the results represent the mean $+\mathrm{sd}$ of three independent measurements for the 639 Transwell@ inserts for each condition (three biological replicates, $n=3$ ). For $\mathrm{A}, \mathrm{pH}$ results 640 for the BoC devices represent a unique measurement per condition (one replicate, $\mathrm{n}=1$ ). For $641 \mathrm{~B}$ and $\mathrm{C}, \mathrm{Ca}^{2+}$ and oxalic acid results for the $\mathrm{BoC}$ devices represents the mean $+\mathrm{sd}$ of two 642 measurements per condition (one replicate).

643

644 Fig. 4. Cytopathic effect of Aspergillus niger on differentiated bronchial tissue and 645 lactate dehydrogenase (LDH) measurements of the co-culture between $A$. niger and 646 Cupriavidus oxalaticus in Transwell ${ }^{\circledR}$ inserts and bronchiole-on-a-chip (BoC) devices.

647 (A) Control showing healthy differentiated bronchial epithelial cells. (B) Bronchial epithelial 648 cells infected with A. niger. (C) LDH leakage was measured as a proxy for cell damage. In the 649 presence of the fungus, no LDH has been detected, probably because of the destruction of the 650 tissue by $A$. niger (B). C. oxalaticus cause significantly more LDH leakage that the basal 651 LDH level of control cells (p-value $=0,004$ ). C: lung cells; $\mathrm{C}+\mathrm{F}$ : lung cells + fungus; $\mathrm{C}+\mathrm{B}$ :

652

653

654

655

656

657

658

659

660

661

662

663

664

665 lung cells + bacteria; $\mathrm{C}+\mathrm{F}+\mathrm{B}$ : lung cells + fungus + bacteria. For $\mathrm{C}$, the results represent the mean + sd of three independent measurements for the Transwell@ inserts for each condition (three biological replicates, $\mathrm{n}=3$ ). $\mathrm{LDH}$ results for the $\mathrm{BoC}$ devices represents the mean $+\mathrm{sd}$ of three measurements per condition (one replicate, $\mathrm{n}=1$ ).

Fig. 5. Genomic screening of the oxaloacetate acetylhydrolase (OAH) in other Aspergillus spp. Multiple sequence alignment of the protein sequences orthologous to the OAH of A. niger CBS 513.88 (GenBank accession number CAD99195.1) revealed they were well conserved across diverse species, as indicated by an intense purple color of the amino acids. Multiple sequence alignments were performed using the MUSCLE protein alignment algorithm in Jalview (version 2.11.1.2). An = A. niger CBS 513.88, ATET = A. terreus $\mathrm{NIH} 2624, \mathrm{AFL} 2 \mathrm{~T}=$ A. flavus NRRL 3357, Afu $=$ A. fumigatus Af293, $\mathrm{AFUB}=$ A. fumigatus A1163, NFIA = Neosartorya fisheri NRRL 181 (formerly A. fisheri). 
666 Tables

667 Table 1. Bacterial and fungal strains used

\begin{tabular}{lllll}
\hline Code & Strain \# & Species & Fluorescent tag & References \\
\hline Pp & NEU 1264 & Pseudomonas putida KT2440 & GFP & $(56)$ \\
Cn & NEU 1286 & Cupriavidus necator JMP289 & GFP & $(57)$ \\
Co & NEU 1287 & Cupriavidus oxalaticus Ox1 & mCherry & $(58)$ \\
An & NEU M8 & Aspergillus niger & - & $(59)$
\end{tabular}

668 All the bacterial and fungal strains used in this study come from the collection of the 669 Laboratory of Microbiology of the University of Neuchâtel.

670

671 Table 2. Culture media recipes

\begin{tabular}{lll}
\hline Medium & Composition & References
\end{tabular}

ALI (Air- $1: 1$ of DMEM/F12 (Cat.\# 11320033, Thermo Fisher (40)

Liquid Scientific) and LHC Basal Medium (Cat.\# 12677019,

Interface) Thermo Fisher Scientific)

BHIA (Brain 37 g Brain Heart Broth (Sigma-Aldrich, Darmstadt,

Heart Infusion Germany), 15 g agar (Biolife Italiana, Milano, Italy), per

Agar liter of deionized (DI) water

MA (Malt $12 \mathrm{~g}$ of malt extract (Sios Homebrewing GmbH, Wald, Agar) Switzerland), $15 \mathrm{~g}$ agar (Biolife Italiana, Milano, Italy), per liter of deionized (DI) water

MA 1/10 $1.2 \mathrm{~g}$ of malt extract (Sios Homebrewing GmbH, Wald, Switzerland), $15 \mathrm{~g}$ agar (Biolife Italiana, Milano, Italy), per liter of deionized (DI) water

For liquid malt 1/10, no agar was added.

NA (Nutrient 23 g NA (Carl Roth, Karlsruhe, Germany), per liter of Agar) deionized (DI) water 
PDA (Potato 39 g PDA (Carl Roth, Karlsruhe, Germany), per liter of

Dextrose deionized (DI) water

Agar)

R2A

$0.5 \mathrm{~g}$ yeast extract, $0.5 \mathrm{~g}$ Bacto Peptone, $0.5 \mathrm{~g}$ casamino

(Reasoner's 2 acids, $0.5 \mathrm{~g}$ glucose, $0.5 \mathrm{~g}$ soluble starch, $0.3 \mathrm{~g}$ Na-pyruvate,

Agar) $\quad 0.3 \mathrm{~g} \mathrm{~K}_{2} \mathrm{HPO}_{4}, 0.05 \mathrm{~g} \mathrm{MgSO}_{4} \cdot 7 \mathrm{H}_{2} \mathrm{O}, 15 \mathrm{~g}$ agar, per liter of

Milli-Q ${ }^{\circledR}$ water

For liquid R2 medium, no agar was added.

WYA + BP $\quad 1 \quad \mathrm{~g} \mathrm{~K}_{2} \mathrm{HPO}_{4}, 5 \mathrm{~g} \mathrm{NaCl}, 0.1 \mathrm{~g}$ yeast extract, $10 \mathrm{mg}$

(Water Yeast bromocresol purple, $20 \mathrm{~g}$ agar, per liter of Milli-Q® water

Agar)

672 
bioRxiv preprint doi: https://doi.org/10.1101/2020.08.20.259929; this version posted December 20,2020. The copyright holder for this preprint (which was not certified by peer review) is the author/funder, who has granted bioRxiv a license to display the preprint in perpetuity. It is made available under aCC-BY-NC-ND 4.0 International license.

\section{$673 \quad$ Figures}
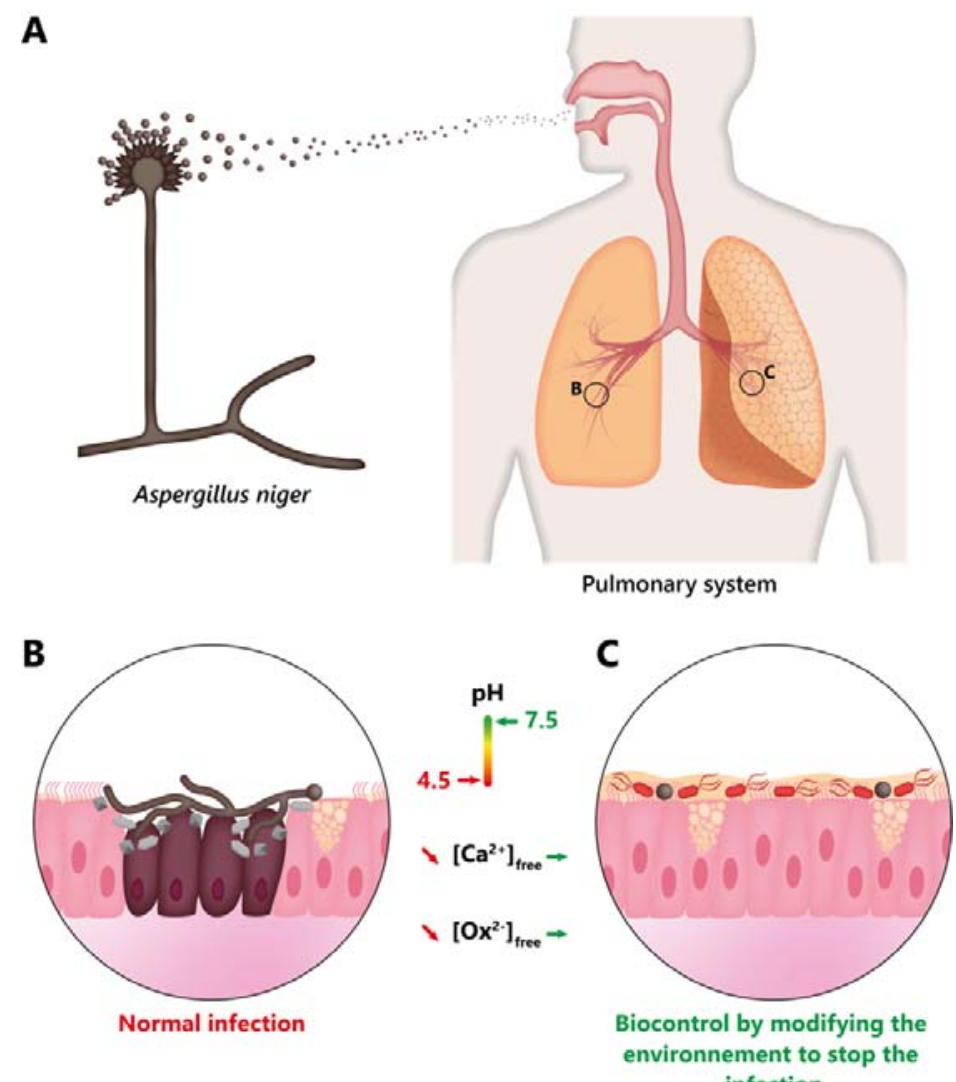

674 infection

\section{Fig. 1.}

676 
bioRxiv preprint doi: https://doi.org/10.1101/2020.08.20.259929; this version posted December 20, 2020. The copyright holder for this preprint (which was not certified by peer review) is the author/funder, who has granted bioRxiv a license to display the preprint in perpetuity. It is made available under aCC-BY-NC-ND 4.0 International license.

677

An + Co

A

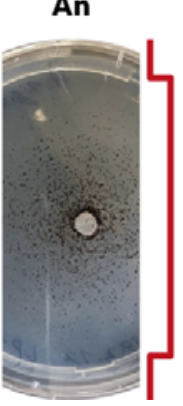

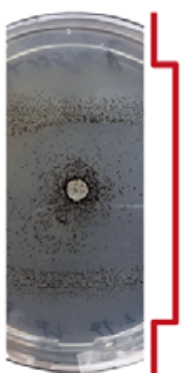

An

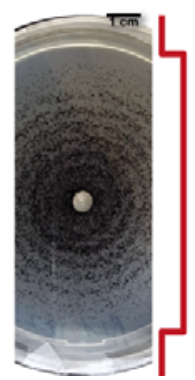

An + Co

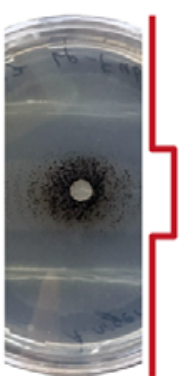

An

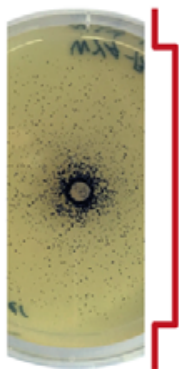

An + Co

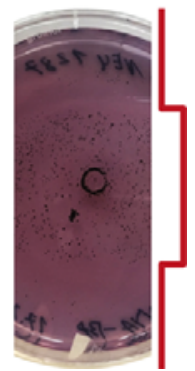

$678 \quad$ Fig. 2.

679 
bioRxiv preprint doi: https://doi.org/10.1101/2020.08.20.259929; this version posted December 20, 2020. The copyright holder for this preprint (which was not certified by peer review) is the author/funder, who has granted bioRxiv a license to display the preprint in perpetuity. It is made available under aCC-BY-NC-ND 4.0 International license.

A

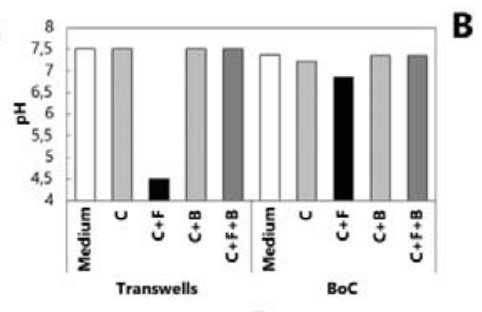

B

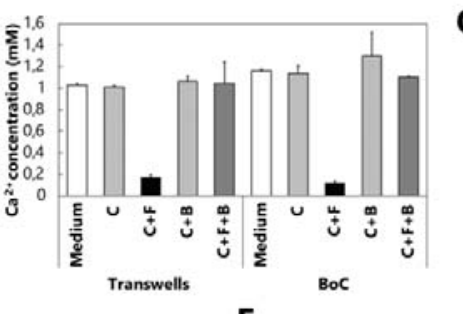

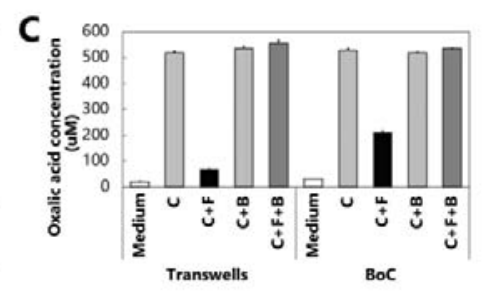
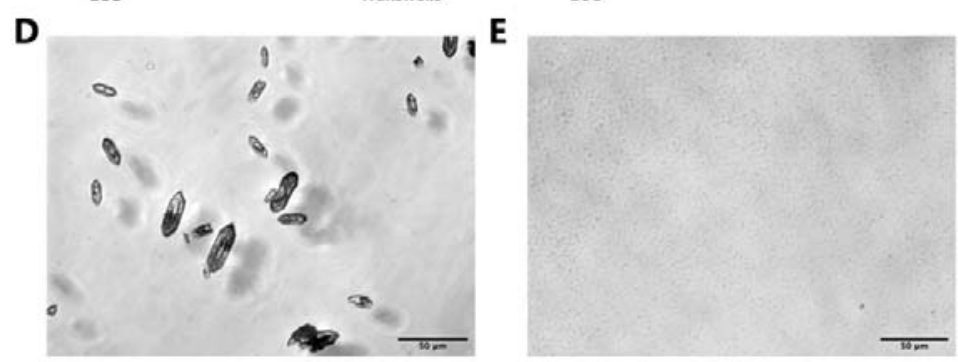

681

Fig. 3. 
bioRxiv preprint doi: https://doi.org/10.1101/2020.08.20.259929; this version posted December 20, 2020. The copyright holder for this preprint (which was not certified by peer review) is the author/funder, who has granted bioRxiv a license to display the preprint in perpetuity. It is made available under aCC-BY-NC-ND 4.0 International license.
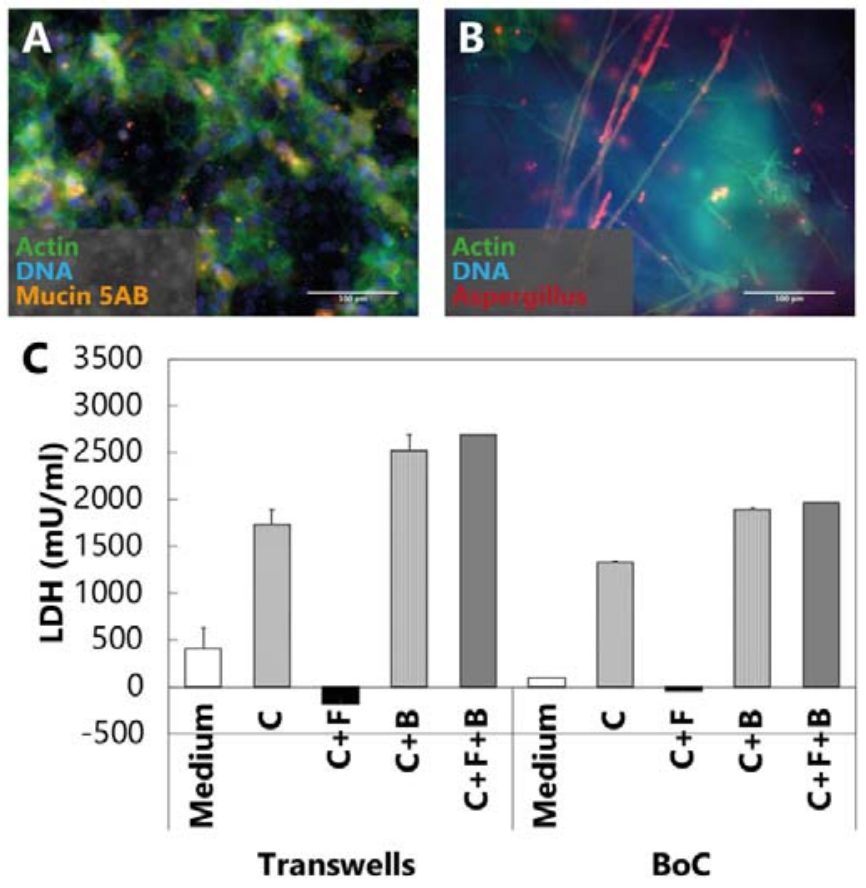

682

683 Fig. 4. 
bioRxiv preprint doi: https://doi.org/10.1101/2020.08.20.259929; this version posted December 20, 2020. The copyright holder for this preprint (which was not certified by peer review) is the author/funder, who has granted bioRxiv a license to display the preprint in perpetuity. It is made available under aCC-BY-NC-ND 4.0 International license.
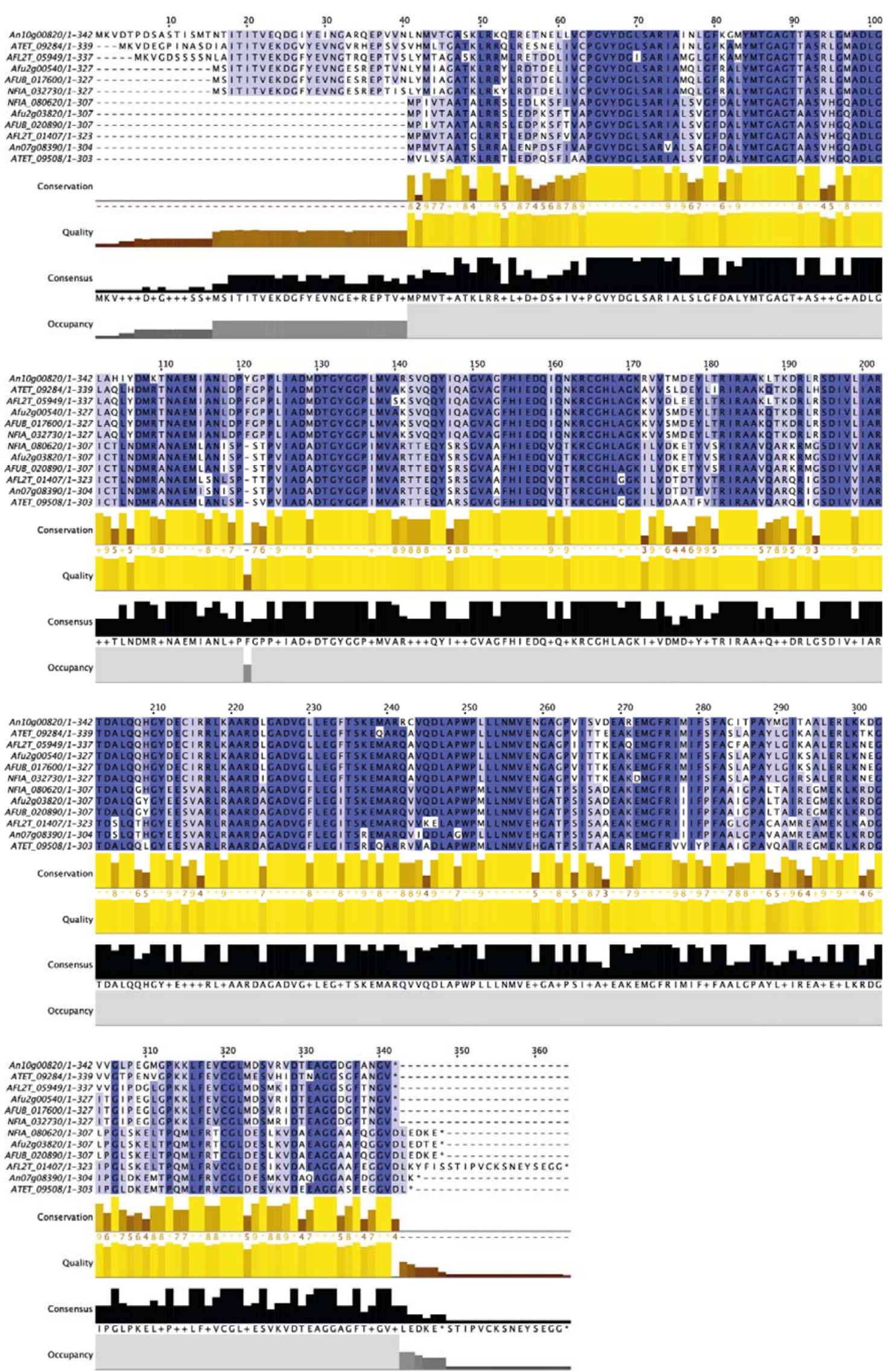
bioRxiv preprint doi: https://doi.org/10.1101/2020.08.20.259929; this version posted December 20, 2020. The copyright holder for this preprint (which was not certified by peer review) is the author/funder, who has granted bioRxiv a license to display the preprint in perpetuity. It is made available under aCC-BY-NC-ND 4.0 International license.

\section{Fig. 5.}


A

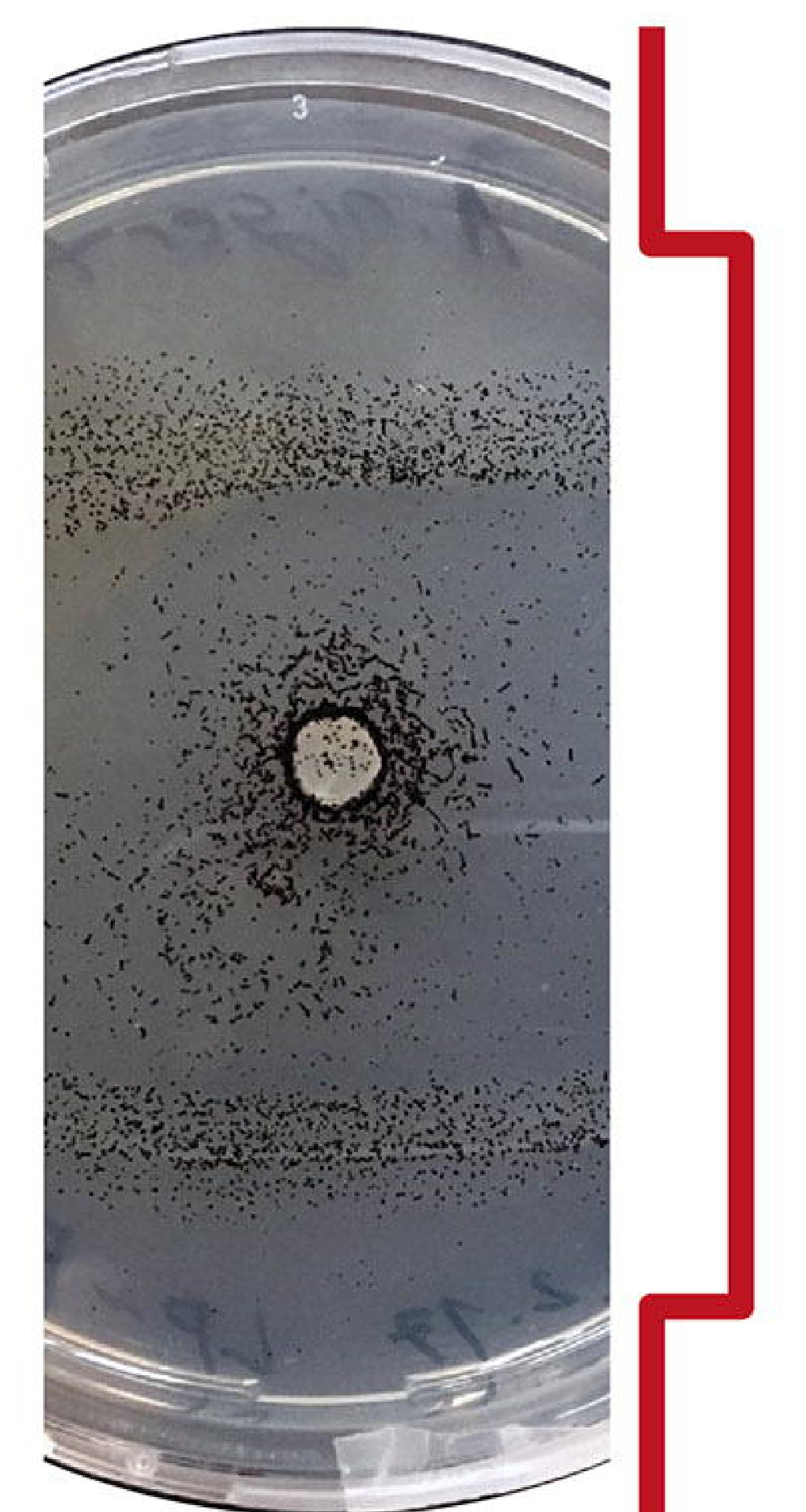

B

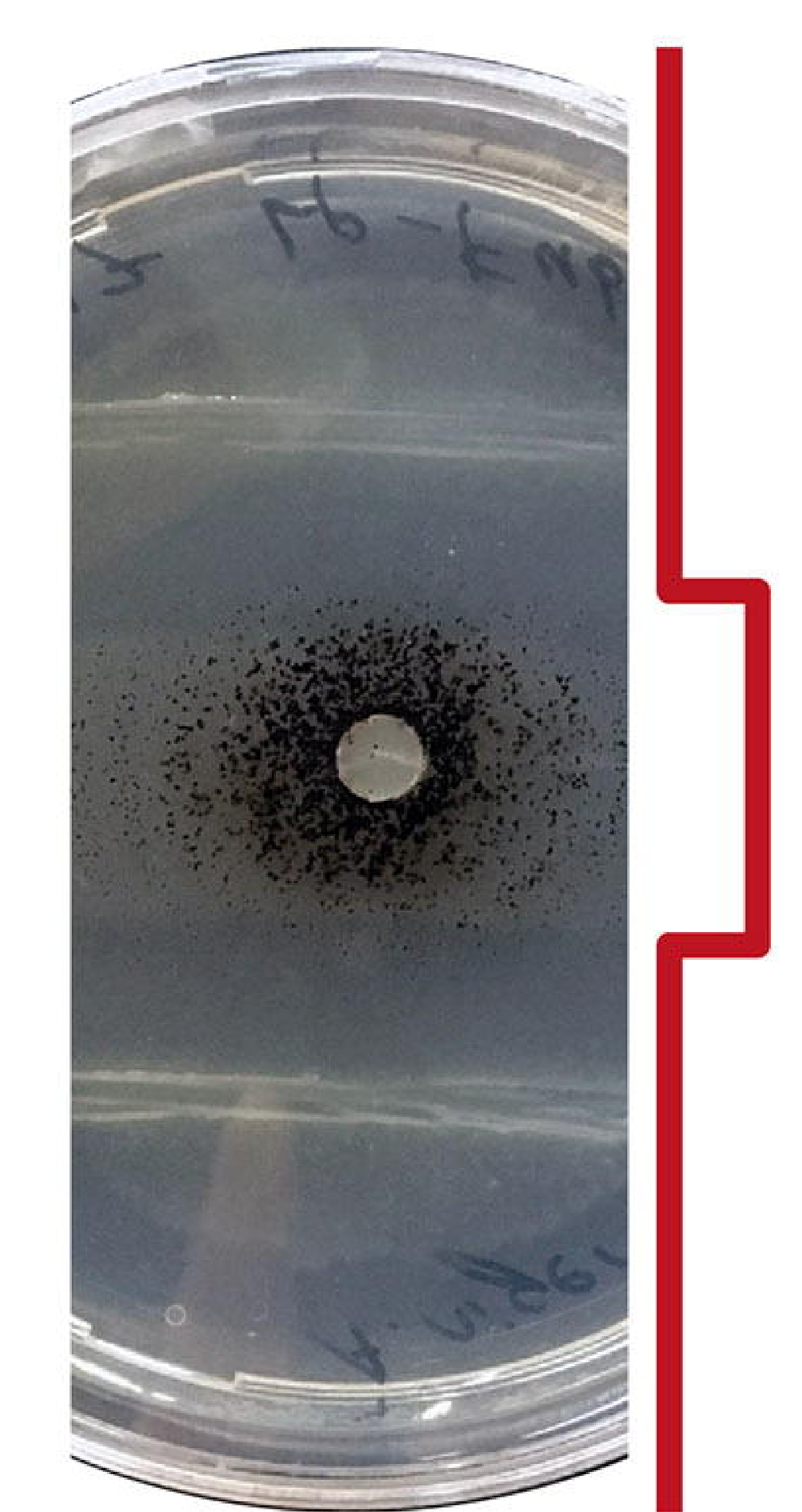

C
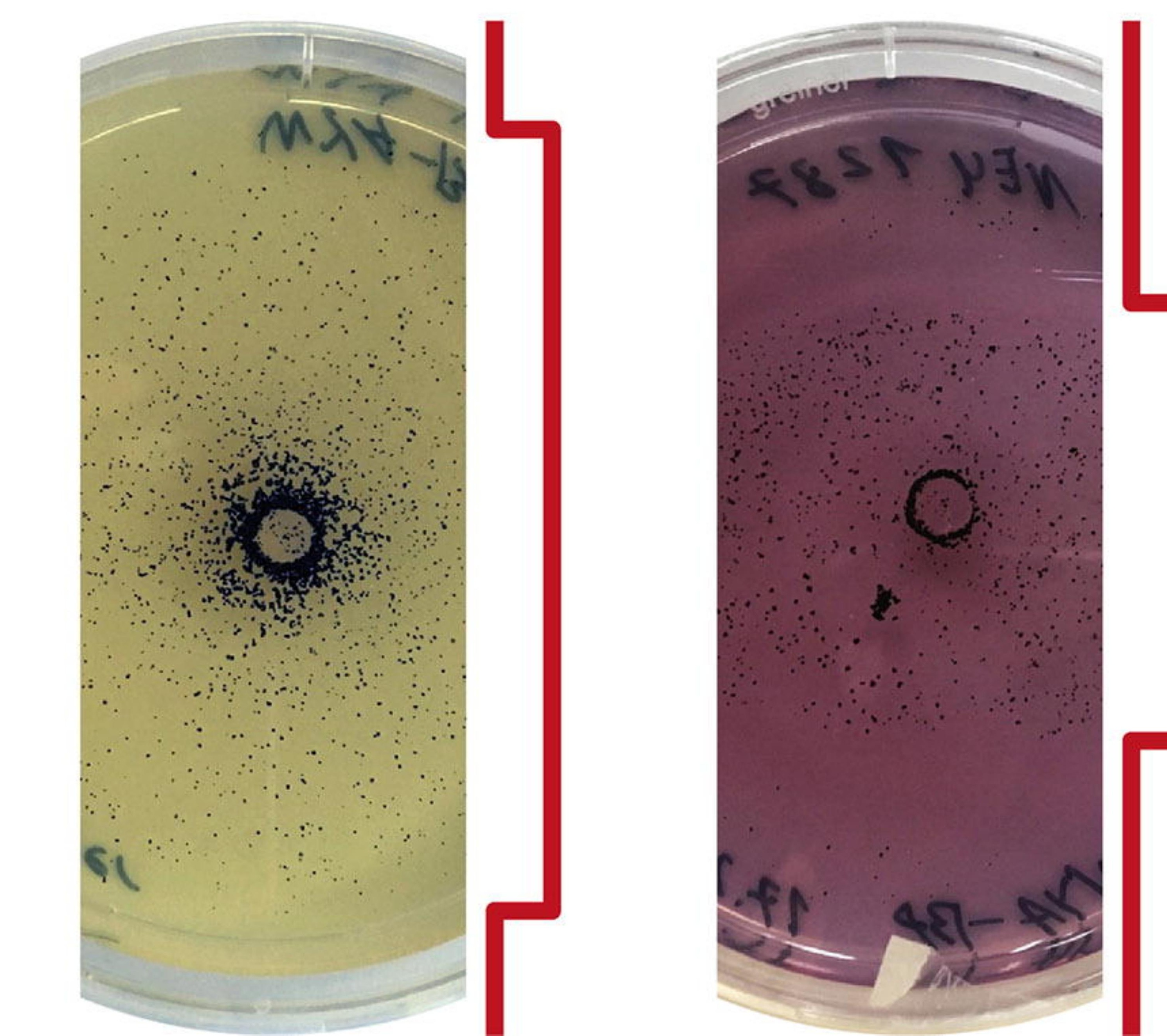


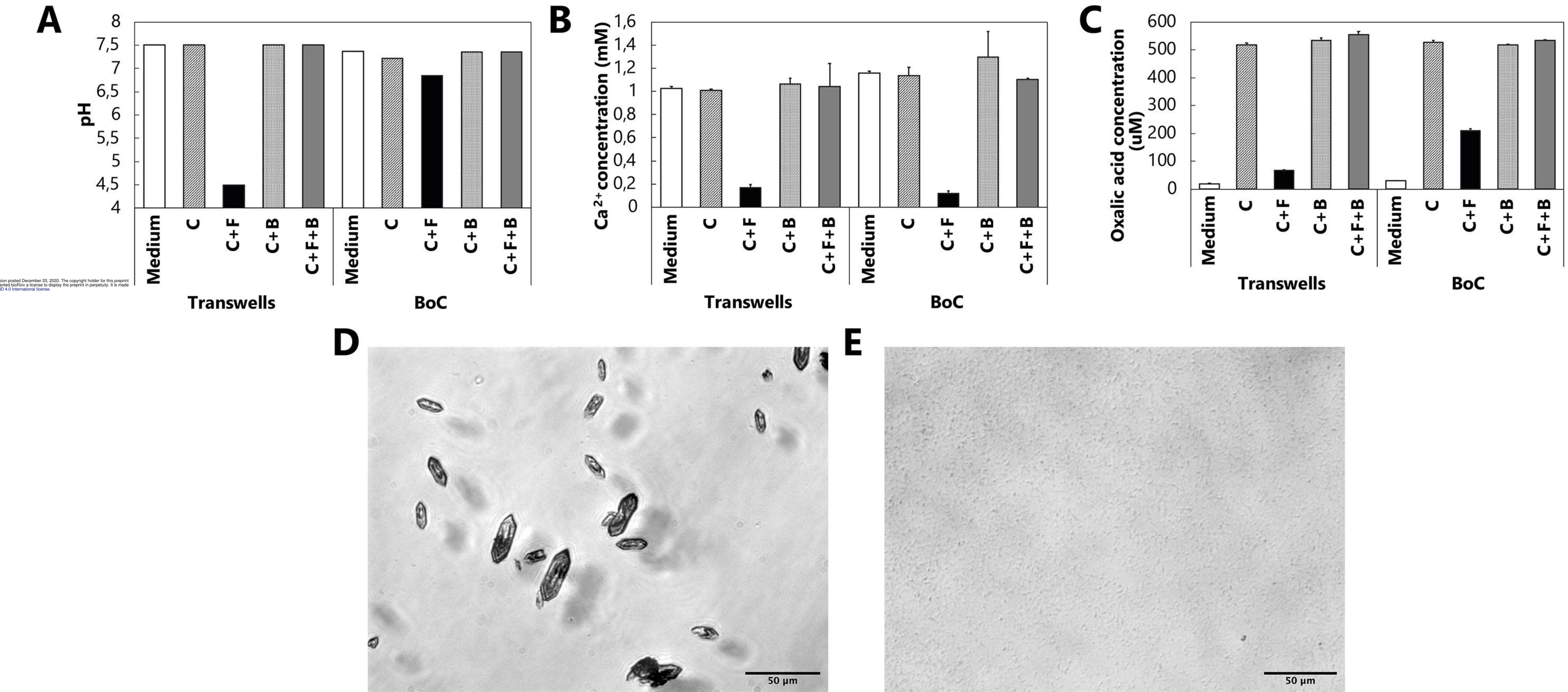




\section{A}

B

Actin

DNA

DNA

Mucin 5AB

C 3500

3000

हิ 2500

छ 1500

工 1000

500

0

$-500$

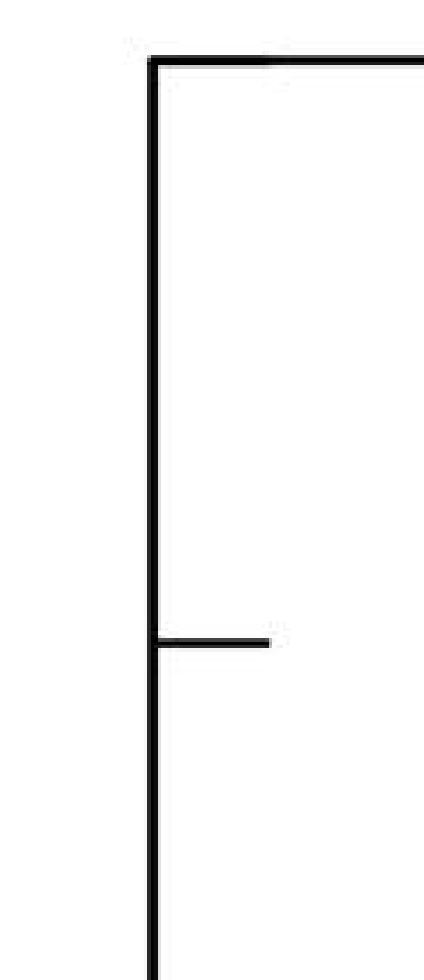



Afu2g00540/1-327--1 - MS I I I TVEKDGFYEVNGESREPTVNLYM I AGATKLRRYLRDTDEL I VCP GVYDGLSAR I AMQLGFRALYMTGAGTTASRLGMAD

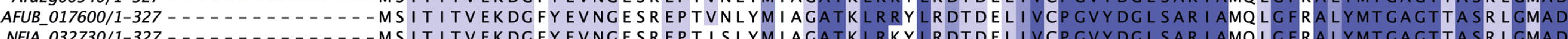

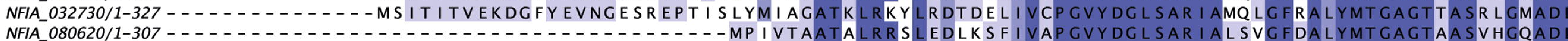
NFA_080620/1-307-1

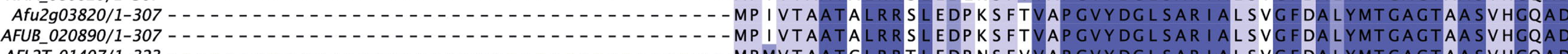
AFL2T_01407/1-323 ATET_09508/1-303 MPMVTAATGLRRTLEDPNSFVVAPGVYDGLSARIALSVGFDALYMTGAGTAASVHGQAD MPMVTAATSLRRALENPDSFIVAPGVYDGLSARVALSAGFDALYMTGAGTAASVHGQADL

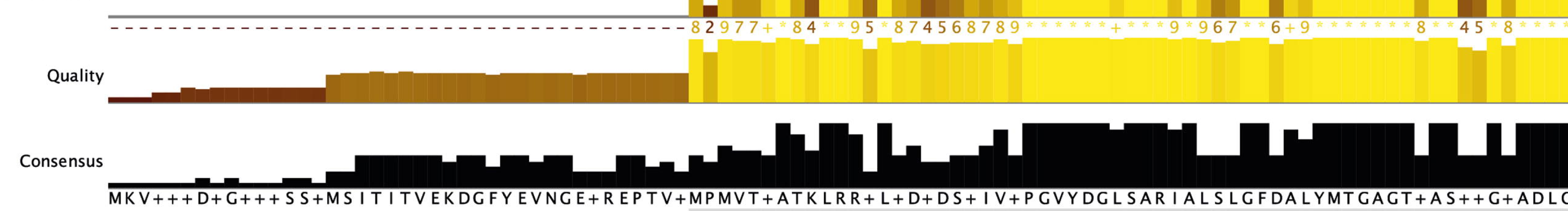

Occupancy

\section{0}

120

130 140

150 160

170

180 190 200 An10g00820/1-342 LAH I Y DMK TNA EM I ANLDPYGPP L I ADMDT GYGGP LMVAR SVQQY I QAGVAGFH I EDQ I QNKR CGHLAGKR VVTMDEY LTR I RAAKLTKDR LR SD IVL I A

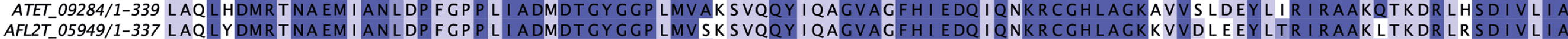

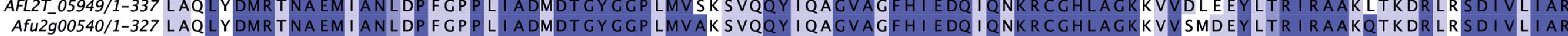

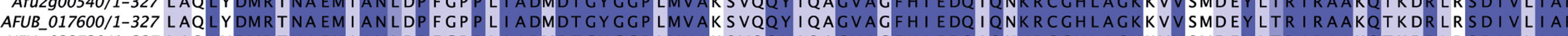
NFIA_032730/1-327 LAQ LYDMRTNAEM I ANLDP FGPP L I ADMDT GYGGPLMVAKSVQQY I QAGVAGFHI EDQ I QNKRCGHLAGKKVVSMDEY LTR IRAAKQTKDR LR SDI VL I A

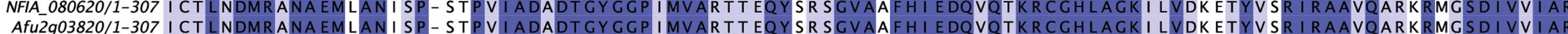

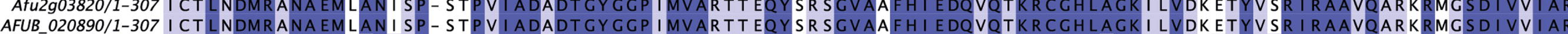

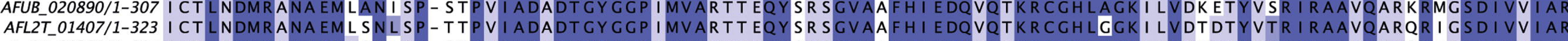

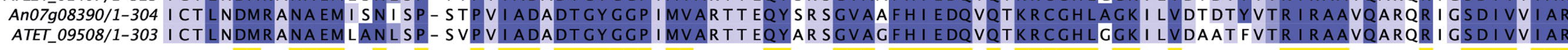

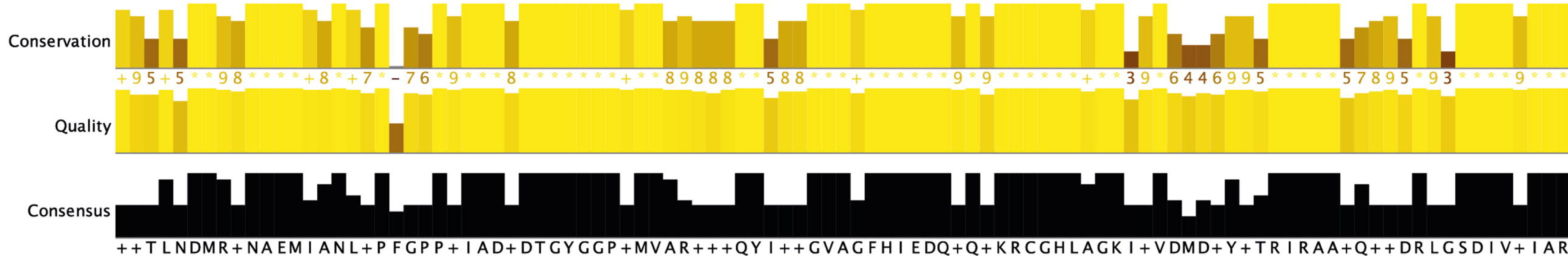

++ TLNDMR+NAEMIANL+PFGPP+ IAD+DTGYGGP+MVAR+++QYI++GVAGFHIEDQ+Q+KRCGHLAGKI+VDMD+Y+TR IRAA+Q++DRLGSDIV+ IA

Occupancy

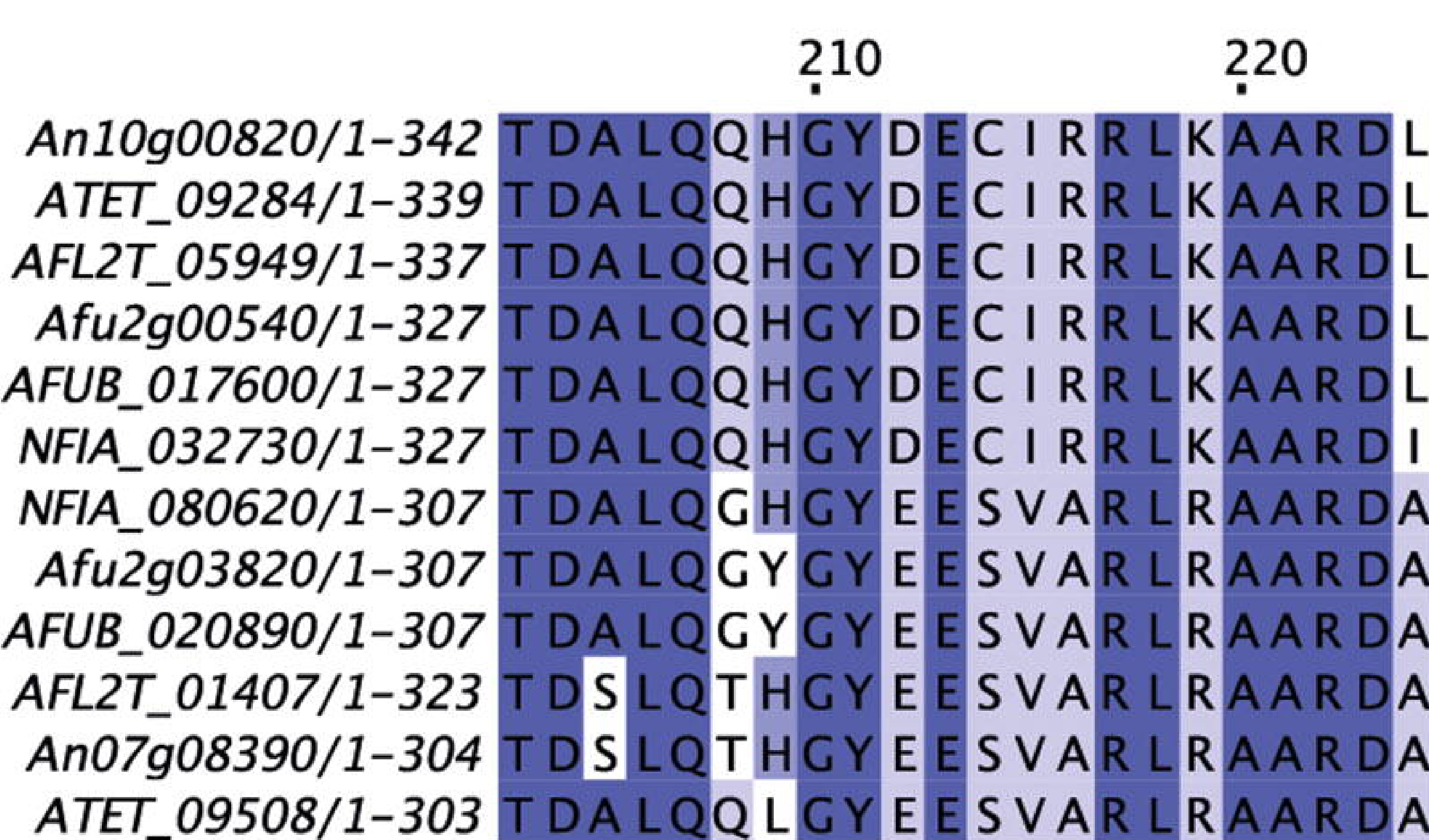

230

240

250

260 270

290 300 ATET_09508/1-30

Conservation H. Th.

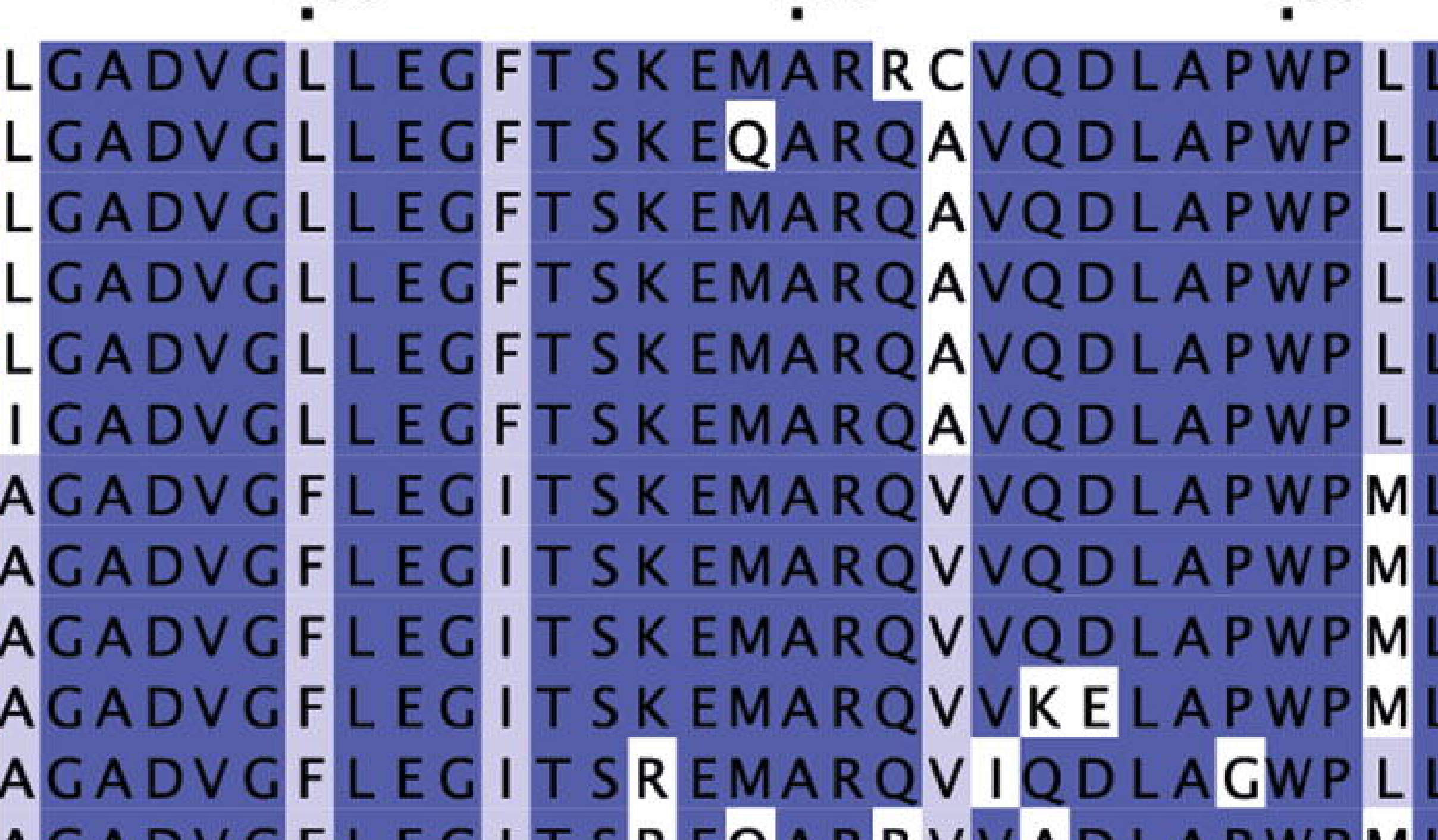

NGAGPVISVDEAREMGFR IMI FSFAC ITPAYMG ITAALER LKKD
NGAGPV ITTEEAKEMGFR IMI F SFASLAPAYLG IKAALERLKTK

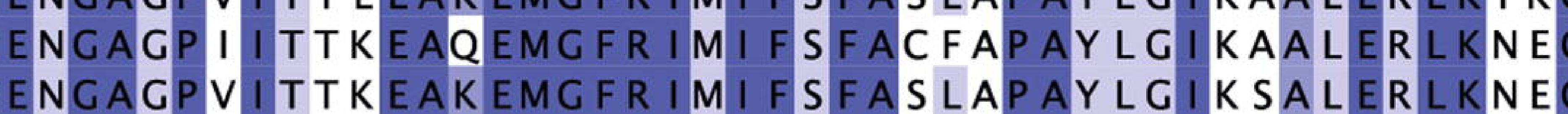
ENGAGPV ITTKEAKEMGFR IMI FSFASLAPAYLG IKSALERLKNE
ENGAGPV ITTKEAKEMGFR IMI I SFASLAPAYLG IKSALERLKNEG ENGAGPV ITTKEAKDMGFR IMIIFSFASLAPAYLGIRSALERLKNEG
EHGATPS ISADEAKEMGFR I I I FPFAA I GPALTA IREGMEKLKRDG EHGATPS ISADEAKEMGFR I I IFPFAA I GPALTA IREGMEKLKRD
EHGATPS ISADEAKEMGFR I I IFPFAA I GPALTA IREGMEKLKRD

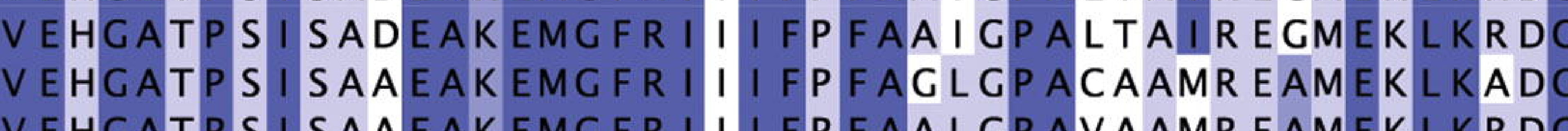
HGATPSITAAEAREMGFRVVIYPFAA I GPAVQAIREGMEKLKRDG

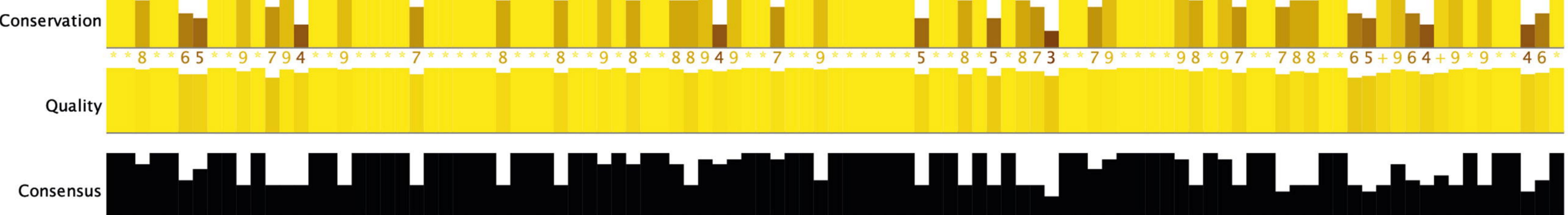

TDALQQHGY+E+++RL+AARDAGADVG+LEG+TSKEMARQVVQDLAPWPLLLNMVE+GA+PSI+A+EAKEMGFRIMIF+FAALGPAYL+ IREA+E+ LKRDG

Occupancy

310 330 350

360

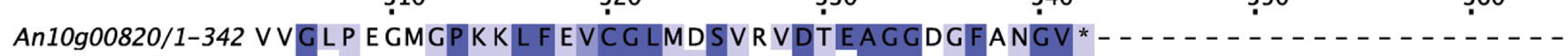

ATET_09284/1-339 VVGTPENVGPKKLFEVCGLMESVH I DTNAGCSGFANGV AFL2T_05949/1-337 VVG I P DGLGPK K L FEVCCLMDSMK I DTEAGGSG F TN AFUB_017600/1-327 I T G I P E GLGPKK LFEVCGLMDSVR I DTEAGGDG F N NFIA_032730/1-327 I T I PEGLGPKKLFEVCGLMDSMR I DTEAGGDGFTNG AA Afu2g03820/1-307 LP GL S K E LTPQM L FRT C L DE S LKV DA EAGGAAFQG VD L EDT

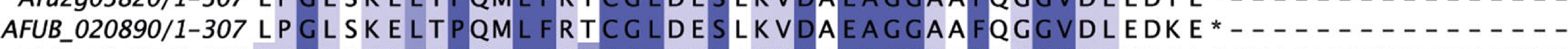
AFL2T_01407/1-323 I P GLSKELTPQMLFR VCGLDE S I KVDAEAGGAAFEGGVDLKYF I S ST I PVCKSNEYSEGG*

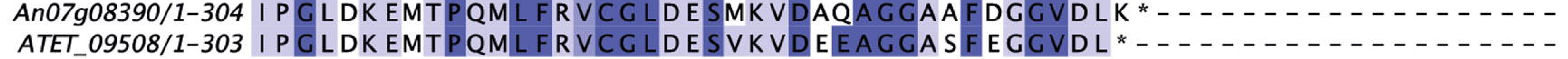

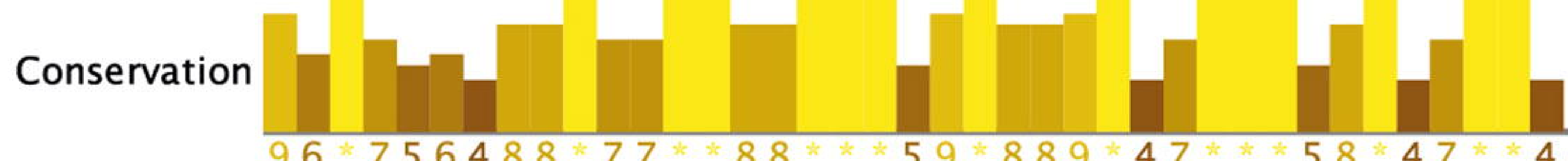

Consensus

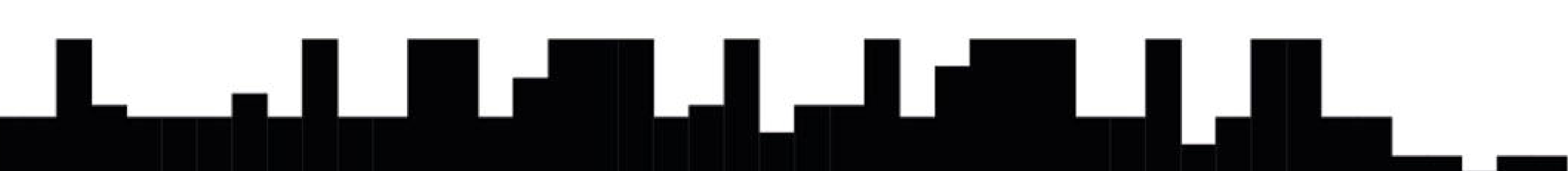

IPGLPKEL+P++LF+VCGL+ESVKVDTEAGGAGFT+GV+LEDKE*STIPVCKSNEYSEGG * 